\title{
The Influence of Personal and Organizational Factors on Researchers' Attitudes towards Sustainable Research Productivity in Saudi Universities
}

\author{
Fahad Ghabban ${ }^{1,2}$, Ali Selamat ${ }^{3,4,5,6, *(\mathbb{C})}$, Roliana Ibrahim ${ }^{1}$, Ondrej Krejcar ${ }^{6}{ }^{\circledR}$, \\ Petra Maresova ${ }^{6}\left({ }^{\circ}\right.$ and Enrique Herrera-Viedma ${ }^{7(0)}$ \\ 1 Information System, School of Computing, Faculty of Engineering, Universiti Teknologi Malaysia, \\ Johor 81310, Malaysia \\ 2 Faculty of Computer Science and Engineering, Information System Department, Taibah University, \\ Madinah 41411, Saudi Arabia \\ 3 Media and Games Center of Excellence (MagicX), Universiti Teknologi Malaysia, Johor 81310, Malaysia \\ 4 School of Computing, Faculty of Engineering, Universiti Teknologi Malaysia, Johor 81310, Malaysia \\ 5 Malaysia Japan International Institute of Technology, Universiti Teknologi Malaysia, \\ 54100 Kuala Lumpur, Malaysia \\ 6 Faculty of Informatics and Management, University of Hradec Kralove, Rokitanskeho 62, \\ 50003 Hradec Kralove, Czech Republic \\ 7 Andalusian Research Institute in Data Science and Computational Intelligence, University of Granada, \\ 18071 Granada, Spain \\ * Correspondence: aselamat@utm.my or viedma@decsai.ugr.es
}

Received: 26 June 2019; Accepted: 15 August 2019; Published: 3 September 2019

check for updates

\begin{abstract}
Purpose: This paper studies organisational and personal factors affecting the behaviour of academic staff in Saudi universities. It seeks to investigate the beliefs of academic staff regarding the use of ICT and other factors to enhance the productivity of their scientific research. Also, this study aims to improve the sustainability of publication in Saudi universities. ICT includes using the library system for accessing research repository databases such as Science Direct, Web of Science, Scopus, etc. and other factors. The authors also developed the Importance Performance Map Analysis (IPMA) for these factors in order to provide guidelines for Saudi universities to build university systems to manage and measure the research productivity of academic staff. In summary, this research identifies factors critical to enhancing research productivity in Saudi universities. This will help to improve the sustainability of publication in Saudi universities. By enhancing the sustainability of publication, the reputation of Saudi universities will be improved and the reputation of academic staff in Saudi universities. As well the sustainability of publication will assist the promote of Saudi academic staff. Approach: This paper analysed 200 papers related to the enhancement of research productivity from various research databases such as Science Direct, IEEE and Scopus. We included the usage of ICT in research analysis, university policy, university research funding and the number of publications published by academic staff. The authors used different databases and systematic literature reviews (SLR) to find the most important factors which could improve research productivity in universities. An online questionnaire answered by 375 academic staff from four developing Saudi universities that are Taif University, Taibah University, Jeddah University, Hail University-was used to determine the relationship between information technology factors and research performance together with other factors such as university policy, international collaboration, research funding and job satisfaction. In this study, we used SmartPLS v3 to analyse the results from the questionnaires. Findings: The results show that personal factors such as personal use of ICT and organisational factors such as job satisfaction, university policy, IT funding, international collaboration and the level of ICT use in the university have positive effects on scientific research productivity among academic staff at Saudi universities. Those results are based on the beliefs of academic staff regarding the use of information
\end{abstract}


technology for research purposes and other factors. This paper finds that university policy recorded an importance of 0.523 , job satisfaction was 0.224 , international collaboration was 0.103 , personal use of ICT was 0.102 , the level of using ICT in the university was 0.074 and the importance of ICT funding was -0.156 . Also, the results from SmartPLS show that university policy has a 0.215 effect size on research performance, job satisfaction has a 0.045 effect size on research performance, international collaboration has a 0.009 effect size on research performance, personal use of ICT has a 0.011 effect size on research performance, a university's use of ICT has a 0.006 effect size on research performance and ICT funding has a 0.014 effect size on the research performance of academic staff in Saudi universities. These results will help to improve the sustainability of publication in Saudi universities in order to enhance the universities' rankings and the reputation of academic staff. Sustainability is a target for any organization, both for profit-making entities or non-profit organizations such as universities. This means that Saudi universities should enhance the sustainability of their publication. In order to achieves the goals of higher education institutions. Originality: No study has investigated the factors affecting the performance of academic staff in Arab countries, especially in Saudi universities. Therefore, the originality of this study resides in being the first study to investigate the impact of researchers' attitudes to enhancing the research productivity performance of researchers in Saudi universities. Also, it is one of the few studies which discusses sustainability in Saudi universities.

Keywords: research productivity; ICT; Job satisfaction; International collaboration; policy; Saudi universities; sustainability in management; sustainable leadership; systematic review; biometric analysis; scientometric analysis

\section{Introduction}

Universities provide the foundations for the nation, society, culture, technology, and economy. The academic programmes offered by academic institutions help to build human capital and research activities [1]. According to Hladchenko [2], knowledge is the most important component for a nation to progress. Three main factors assist a nation's economy. Those factors are important for both industry and academia. The relationship between industry and academia has a positive influence on universities and industry, and both of them can enhance the economy. Universities are an essential component of the innovation ecosystem for societal development. They generate and transmit knowledge and act as a workplace for the discovery of new knowledge by enhancing the creativity of students and academic staff. Knowledge can be shared, discussed and expanded in the research environments which have been developed in university eco-systems [3]. Industries often depend on universities to do research in order to expand the industry and enhance innovation [1]. It is mean universities should use this opportunities to find new research area to publish.

According to James [4], the two goals of universities are to drive their research and balance both teaching and research quality. According to Barnett [4], universities and higher education institutions are places to establish learning. According to Damon [5], explained that research refers to the time researchers spend in contemplation. A scholar's time is the first input in the research process, and a researcher's contemplation is a process in itself. According to Santos and Horta [6], a research agenda can be defined as the combination of strategic problem-solving frameworks to achieve the research goals in the organization. Having a research agenda is the best way to enhance research productivity and make the measurement of academic progress easy to monitor.

The Kingdom of Saudi Arabia has 26 universities which are overseen by the Saudi government [7]. Saudi Arabia has three generations of established universities, and all of them established since 2005 are considered as under-developed universities. Saudi Arabia has 18 under-developed universities. Those universities still receive extra funding from government to build their infrastructure, such as IT infrastructure and research equipment. The primary aim of Saudi universities is to enhance research 
and development in the nation [8,9]. According to Alhaider [10], research productivity is a primary indicator which is used to determine the performance of Saudi universities, and publications and citations are two critical indicators to evaluate research productivity performance [11-13]. However, the current reality in Saudi universities is that they have low research productivity due to their limited publication output $[7,9,14]$. Saudi universities rank the lowest among other developing countries in terms of their number of publications [15]. The university ranking is not only a tool to measure the success of a university, but it can also act as a challenge to all universities to improve their scholarly knowledge advancements through publications [16]. The important academic rankings are the Shanghai Ranking, QS World University Ranking, and Time Higher Education World University Ranking. However, Saudi universities did not achieve the objectives stated by the Saudi Higher Education Ministry of reaching the level of international universities' standards and improving Saudi universities' rankings due to their lack of motivation to publish in reputable journals. This is an indicator of minimal innovation and research productivity $[9,17]$.

In a step towards addressing this issue, this paper studies the personal and organisational factors that motivate and assist academic staff in Saudi universities to enhance their research productivity according to their beliefs. We focus on the impact of Saudi university scholars in utilising the usage of ICT to improve their research productivity through online research materials which are accessed through library subscriptions such as Science Direct, web of knowledge, IEEE Explore, etc. and also through public online repositories such as results from Google Scholar, Research Gate, etc. Also, this paper will study other organisational factors such as job satisfaction, international collaboration and university policy.

From 2008 to 2011, Saudi universities had increased numbers of publications; for example, King Saud University had 455 publications in 2007, which then increased to 2500 publication in 2011. This means that the sustainability of publication in Saudi universities is very important. It is critical to find the factors that could aid the sustainability of publication. Sustainability is a target for any organization, both profit-making entities and non-profit organizations such as universities [18]. Sustainability in publication leads to improvements in university rankings and the reputation of academic staff. Thus, researchers should improve the sustainability of publication and research productivity in Saudi universities. According to Brusca [19], sustainability is an important aim for higher education institutions such as universities. Exploring the factors which influence organization and personal issues are the main task in enhancing the sustainability of universities. Also, sustainability in research in universities will assist researchers in finding sources of funding from industry and other sectors. Most of the leading universities around the world aim to enhance their sustainability in research or publication to avoid their ranking decreasing compared with other universities. Several studies agree on the importance of studying personal and environmental factors to enhance employee performance and sustainability. According to Ab Aziz [1], aimed to investigate research dynamics to enhance research productivity in Malaysian universities. The main factors that may affect research productivity performance at universities are government policies, university objectives, researchers' preferences and attitudes, research topics and research type. This means that personal factors and university factors (environmental factors) are important factors to enhance research productivity performance. The study by Haliso [20], aims to investigate the factors which encourage academic staff in Nigeria to use information and communication technology in the library. This study finds that organization factors are the most important factors to enhancing the use of information and communication technology. Organization factors include a lack of ICT strategy and lack of commitment by institutional management, and also other personality factors such as a low level of skill in using ICT. According to Alturise and Alojaiman [21], personal factors and behavioural factors are key factors to success in improving the performance of employees. According to Verbree [22], it is essential to examine the impact of personal factors, behavioural factors and organizational factors on academic staff in universities to improve research productivity performance of academic staff. This research indicates that personal characteristics, behaviour and university factors have significant relationships 
with research productivity for academic staff in universities. According to Bentley [23], indicates that personal factors and organizational factors can influence the number of publications between countries. It is critical to enhance the personal factors and organizational factors to improve research productivity performance in universities. According to Shahbazi [24], personal factors, behavioural factors and university factors are the most important factors to increasing university publication and citation rates.

According to KACT [25], Saudi universities need to improve their sustainability in publication. From 2008 to 2011, Saudi universities have increased numbers of publications; for example, King Saud University had 455 publications in 2007, which then increased to 2500 publications in 2011 . There are many reasons behind this improvement; for example, the Saudi Government has increased the budget to assist scientific research and incentivise academic staff to publish in ISI (Information Scientific Indexing); facilities attend conferences; universities have agreements with language-specialist editors to audit and review their scientific research, meaning that faculty members have increased chances of publication in ISI; international alliances and development programs pursued by universities have obtained increased support from the private sector; and international cooperation, which includes distinctive scientifically published and international staff, to reduce the teaching loads of academic staff $[25,26]$.

\section{The Use of ICT in Saudi Universities}

ICT is essential to growth in organisations. All developing countries plan to enhance the IT use in their organisations to increase the productivity of their workers [27]. According to Vasileiadou [28], the use of ICT is the most important element to improving the productivity of workers in universities. For example, the bandwidth coverage that supports internet usage in universities will assist academic staff in sharing their knowledge with colleagues within the same academic institution, the same country or abroad. The use of computers and communication systems to assist human collaboration dates back to the early 1980s. Now, a computer technology called the Group Support System (GSS) has developed. Groupware is defined as a computer network system that provides a shared interface for participating groups to enhance communication [29]. According to Edward [30], ICT can affect the improvement of academic staff's performance. New software technology for personal productivity and research documentation can help academic staff in universities to store knowledge and reproduce knowledge easily. Knowledge is not only the most important resource in the organisation but is a primary source of competitive advantage. Knowledge is an important element in maintaining the sustainability and success of any private or public organisation [31]. The use of ICT and the learning culture are significant variables that affect knowledge sharing in higher institutions [31].

On the other hand, there are several disadvantages of using IT on the individual level, organisation level and society level. The impaired feeling of belonging, feeling of isolation and lack of professional support are the most common disadvantages on the individual level. The cost, possible damage to commitment and training are the most common disadvantages on the organisational level [32]. Also, using online forms to collect data can affect negatively the accuracy of the results [33].

According to Alharthi [34], the Saudi Arabian IT market is considered to be the largest IT market in the Gulf region, valued at around 3.4 billion dollars. The Saudi government has invested around 3.1 billion Saudi Riyals (SAR) to improve the education system in order to improve the education in the country. The current reality of using IT in Saudi Arabia is that there is a shortage of use from a research perspective [35]. According to Kahtani [36], Saudi academic staff are at the lowest percentage in terms of having access to the internet in their home and workplace. Most female academic staff in Saudi universities believe that using the internet is dangerous. A very small number of Saudi academic staff use ICT to search for knowledge or transfer knowledge [36].

Moreover, Saudi universities have a low level of financial IT resources to help with teaching, research and learning. Saudi universities are still in the first stage of using cloud computing to facilitate open access for students and research [34]. Only four out of 26 universities are using cloud computing in teaching and e-learning [34]. This study will examine the impact of using ICTs, such as cloud 
computing (computer-based communication), Web 2.0 technology, software use for research (i.e., SPSS-AMOSS, EndNote, NVivo, Turnitin, Microsoft office, etc.), online discussion platforms and IT infrastructure, on academic staff in Saudi universities to enhance performance in terms of research productivity. This study explores information technology as a tool used to enhance the research productivity performance in Saudi universities [37].

According to Al-Ghamdi [38], higher education in Saudi Arabia is seeking to move from traditional methods to cloud-based education in order to follow developing countries and improve the performance of teaching and research. By using ICT, the research productivity of academic staff in Saudi universities will improve. Moreover, it will improve international collaboration, which is one of the main objectives of higher education in Saudi universities [38]. Using information technology will help Saudi universities and staff to share knowledge, which is highly important in the academic world [39]. Many studies agree that using information technology at the personal level or organization level has a positive effect on the sustainability of publication in the universities. According to Fabregat [40] IT funding is one of the most important factors in enhancing sustainability. There are many studies that indicate the importance of the ability of academic staff to use computers to enhance research productivity; for example, using software in research such as SPSS, AMOS and others [41,42], the ability to use online information retrieval $[43,44]$, and, the ability to use computer-based communication to enhance communication [45-47]. Moreover, it is important to encourage academic staff to believe that attending e-conferences will improve their academic skills $[48,49]$ and to believe that using library systems will enhance their research and academic performance [46,50,51].

Thus, from the above studies, it is clear that there is a low amount of use of ICT in Saudi universities for research purposes. Also, previous studies have shown the importance of using IT to enhance the performance of organizations and their workers. This means that the use of ICT by academic staff in Saudi universities will assist the sustainability of publication and enhance the number of publications.

\section{Personal and Organization Factors}

Several factors can influence academic staff in Saudi universities to improve their research productivity. These factors include job satisfaction, personal characteristics, organisational factors, training, teamwork, PhD students studying in university and requesting to publish, rewards, identifying the main goals of an organisation, mobility, knowledge sharing, university-industry relationships, motivation, measuring staff progress, online platforms and IT infrastructure [22,50,52-57]. They also include research topics, teaching load, experience, university rankings, international collaboration, communication behaviour and the awareness of academic staff [42,58-60]. Several studies have been conducted regarding the impact of using ICT to enhance performance in Saudi universities. However, all of those studies were about teaching performance or academic performance for students. According to Al-Khalifa [9], studies on international academic publication productivity in the Middle East, especially in Saudi Arabia, are hard to find. One previous study investigated the bibliometric studies of Saudi researchers. The researchers discussed the low number of publications by Saudi universities and low impact factors [9]. The authors' mission was concerned with the importance of studying the factors that affect publications by academic staff in Saudi universities. Alturise [21], examined the benefits and challenges of using ICT in Saudi universities for both students and teachers. Also, the authors encouraged ICT researchers to investigate factors that may assist Saudi university staff in ICT use [21]. Alrahlah [61], focuses on the motivational factors of the research productivity of dental faculty members at Taibah University. The authors recommended the importance of examining how research productivity can enhance Saudi universities, as well as finding factors to push Saudi academic staff to publish in high-impact journals [61]. In Al-Kahtani et al. [36], the lowest use of ICT in a research perspective was from female academic staff. Previous studies showed the importance of developing a model to encourage academic staff in Saudi universities to use ICT for research purposes. Eid and Nuhu [31], showed the impact of the learning culture and IT use on knowledge sharing for students at KFUPM University in Saudi Arabia. Future studies should consider respondents from several 
universities and include females to ensure a greater generality of findings. Also, future studies should include other factors that may impact knowledge sharing in Saudi universities [31]. Alghanim [51], recommended that future researchers examine the effect of factors that influence publications by academic staff in Saudi universities. Bajabaa [62], conducted a study in Taibah University in Saudi Arabia to examine the impact of using ICT among faculty members to enhance teaching performance. Another study examined the impact of using Google applications as part of cloud computing to enhance teaching performance in Bisha University in Saudi Arabia [63].

From the above limitations and recommendations, it is vital to investigate the factors affecting the use of ICT by academic staff in Saudi universities for research productivity. Theories in ICT studies to enhance research productivity in Arab countries, especially in Saudi Arabia, are rare. Several studies conducted in developed countries suggest the importance of studying personal and environmental factors to enhance the performance of workers. According to Ab Aziz et al. [1], the main factors that may affect research productivity performance are government policies, university objectives, researchers' preferences and attitudes, research topics and research type. This means that those factors are related to university policies and the personality of academic staff. According to Haliso [20], investigated factors encouraging academic staff to use ICT in libraries. The main factors included organisational factors such as a lack of ICT strategy and lack of commitment by institutional management. Other factors were related to the personality of academic staff, such as a low skill level in ICT use. According to Alturise [21], personal and behavioural factors are the key success factors to improving the teaching performance of academic staff in Saudi Arabia with ICT.

Additionally, the above studies show the importance of this study in examining personal and organisational factors to encourage ICT use and improve research productivity in Saudi universities. The next section will describe each factor via a review of the literature.

Investigating these factors will help Saudi universities to improve their sustainability in publication. This will enhance the income for universities, achieve the goals of universities, enhance the rankings of Saudi universities and improve the reputation of academic staff. Also, there are no previous studies into the factors enhancing publication in Saudi universities, and no studies before have investigated the importance of factors in maintaining the sustainability of publication at Saudi universities. These reasons led the authors to perform an SLR to investigate the factors, then to build a questionnaire to evaluate the relationships between the factors (see results section).

\section{Personal and Organisational Factors}

Several studies agree on the importance of studying personal and environmental factors to enhance employee performance. Ab Aziz et al. [1], investigated the research dynamic to enhance research productivity in Malaysian universities. The main factors that may affect the performance of research productivity at universities are government policies, university objectives, researchers' preferences and attitudes, research topics and research type. This means that personal factors and university factors (environmental factors) are vital to enhancing research productivity performance. Haliso [20], investigated the factors which encourage academic staff in Nigeria to use ICT in the library. The study finds that organisational factors are the most important factors in enhancing the use of ICT. Organisational factors included a lack of ICT strategy and lack of commitment by institutional management and other personality factors such as a low level of skill in using information and communication technology.

Bentley [23], indicated that personal factors and organisational factors could influence the number of publications between countries. This is critical to enhancing the personal factors and organisational factors to improve research productivity performance in universities. According to Shahbazi-Moghadam et al. [24], personal factors, behavioural factors and university factors are the most important factors to increasing university publication and citation rates. Musiige and Maassen [64], studied the factors that influence research productivity at Makerere University. The results show that personal factors, behaviour factors and university factors are associated with the enhancement of 
research productivity in universities. According to Verbree et al. [22], it is essential to examine the impact of personal factors, behavioural factors and organisational factors on academic staff in universities to improve the research productivity performance of academic staff. This research indicates that personal characteristics, behaviour and university factors have a significant relationship with research productivity for academic staff in universities. According to Bengoa et al. [65], it is very important to have research and development activities to enhance research productivity. This underscores the importance of universities.

\section{Personal Factors (Personal Use of ICT)}

Personal factors enhance worker performance. According to Wood [66], research productivity is highly variable and can be influenced by several factors, including personal factors. Ability, energy, creativity, motivation, ambition, and self-discipline are considered important personal factors that define productive and unproductive researchers. Several factors influence research training and productivity in medical sectors in Saudi Arabia. According to Alhaider et al. [10], a lack of research topics, research questions, research tools, and time are considered the main personal factors that affect the research productivity in paediatric residency programmes across Saudi Arabia.

The personal use of e-journals by academic staff can enhance research productivity, as shown in Figure 1. According to Raza and Upadhyay [67], many research scholars consult e-journals from their computers. E-journal training and download speeds are major problems facing academic staff for using e-journals. In recent years, online discussion has rapidly become an important part of learning at any institution and is becoming especially common in higher education [45]. Internet-based technologies are mostly used for online discussion to enhance communication and transfer knowledge [45]. Institutional repositories are a component of the technical infrastructure of research institutions and are a great option for providing open access to research output. Self-archiving is an important personal factor that influences the success of institutional repositories [42]. According to Siddiqui [44], using information and communication technologies in libraries has several advantages, such as the easy integration of various libraries, avoiding duplication, saving money and increasing efficiency.

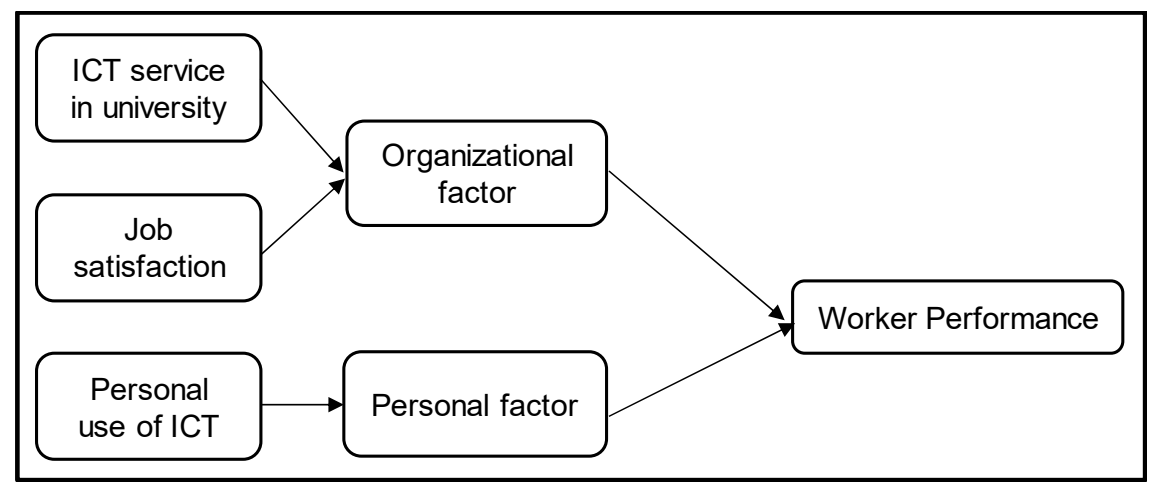

Figure 1. Factors affecting worker performance.

Additionally, using ICT in libraries provides speedy and easy access to information, provides remote access for users, and provides unlimited information from different sources. Al-Shanbari and Meadows [68], found that the personal use of computer applications, such as data collection, the statistical analysis of data, searching online databases, and the use of electronic mail, can affect the performance of research in an organisation. According to Sohail and Daud [47], knowledge sharing is an important aspect of research universities. Personal use of social network websites has a positive impact on enhancing scholarly communication between researchers. The above studies underscore the importance of personal factors. However, some of those factors cannot be achieved without supportive academic staff behaviour. Thus, it is important to investigate the relationship between personal use of ICT for research purpose and the enhancement of research productivity at Saudi universities. 
Hypothesis 1 (H1). Personal uses of ICT are believed by academic staff to be associated positively with publication productivity.

\section{Organisational Factors}

Organisational factors refer to the factors provided via the organisation or institution to support their workers. Most studies use organisational factors as the main factors to increase performance or develop an aspect of the organisation. For Ab Aziz et al. [1], and Cloete et al. [53], it is important for developers or managers to examine organisational factors in order to enhance research productivity. For example, the organisational policy is one of the main motivators to push workers to achieve an organisation's objectives. Organisational policy is considered an organisational factor. According to Hanssen et al. [69], the research environment is an important element to improving the quality of publications.

Job satisfaction is a target that all organisations aim to achieve for their employees. Academic job satisfaction can be measured by the courses taught, relationships with colleagues, job security, promotions, and the way the institution is managed. Job satisfaction is a critical factor and should be considered when encouraging academic staff to enhance their performance [70]. According to Basak and Govender [71], universities must have a positive and healthy climate for university job satisfaction. Satisfaction leads to an increase in academic staff performance in universities. According to Hamermesh and Pfann [72], academic staff salaries in universities have a strong effect on the quality and quantity of their productivity. Relating salary to the number of publications can positively affect job satisfaction for academic staff in universities. The research culture in a university is another of the most important factors in enhancing job satisfaction for academic staff. A lack of research activity in Saudi universities is one of the challenges influencing academic staff in Saudi universities which aim to have more publications.

Wood [66], indicates that job satisfaction is one of the most important factors influencing the progress of the research performance of university academic staff in Australia. According to Basak and Govender [71], job satisfaction is the satisfaction of workers with their job, which will lead workers to love their job. Several factors affect university academic job satisfaction, such as promotional opportunities, individual personal characteristics (age, tenure, educational level, hours of work), supervision, facilities, administration load and salary. Masum et al. [56], found that the job satisfaction of academics is related to demographic characteristics, the work itself, pay and relationships with co-workers. According to Hanssen et al. [69], when the researchers are measured by their publications, their satisfaction will be higher. This means the payment of the academic staff depends on their publications. According to Shin and Jung [73], the factors that influence the job satisfaction of academic staff in a university include their salary, working conditions, technological support, workload, performance-oriented management and research support.

From the above studies, it is important to examine the effect of academic staff job satisfaction on research performance to see which elements can influence the level of satisfaction for academic staff in Saudi universities according to the beliefs of academic staff regarding using information technology and other organizational factors and personal factors for research purposes.

Hypothesis 2A (H2A). Job satisfaction is believed by academic staff to be positively associated with publication productivity.

Many researchers agree that the availability, amount, and continuation of funding is central to facilitating research, and serious problems arise from funding restrictions [74]. Those problems are defined as difficulties in being able to justify some applications in terms of departmental needs, such as technical support or computers [66]. According to Alghanim [51], the lack of computers, lack of technical support, and poor infrastructure are the main obstacles facing academic staff in enhancing their research productivity. Organisational funds can overcome these obstacles. According to Khademi 
et al. [50], the availability of international databases and finance has a strong effect on increasing research output for an organisation. The fund from the organisations can provides both of these. The availability of funds is the primary motivation factor that can be provided by an organisation for academic staff; for example, the availability of funds to build a research laboratory will enhance the satisfaction of academic staff and increase the number of publications [75].

Shirazi [76], found that the poor standard of IT infrastructure is considered to be a barrier affecting the contribution of developing countries' social scholars aiming to publish in ISI journals. According to Raza and Upadhyay [67], the slow download of papers is a major problem faced by researchers in using e-journals. Thus, good IT infrastructure can encourage academic staff to use e-journals to publish or update their knowledge. According to Mairesse et al. [77], IT infrastructure is an important component that has to be provided by an organisation to improve research productivity. Brynjolfsson and Hitt, Lorin [78] and Sangowusi [49], found that using the internet has an important role in enhancing communication and improving performance. Using the internet allows academic staff to use online searching, which helps them to find relevant information easily. Also, Al-Shanbari and Meadows [68], found that being provided with statistical software supports academic staff through easy analysis. The availability of information technology is vital to enhancing communication by improving the virtual work environment [79]. IT infrastructure assists IT integration in the organisation, which will lead to the enhancement of an organisation's performance [80]. It allows students in higher education to use ICT to enhance their skills and improve their level of e-learning [81].

From the above studies, it is clear that funding is an organisational factor that affects research performance in universities. Thus, it is important to examine this factor's level of significance and how the organisation should consider it according to the beliefs of academic staff regarding how universities can use ICT fund to improve research and assist the IT infrastructure to help researchers to publish.

Hypothesis 2B (H2B). The availability of ICT funds is believed by academic staff to enhance research productivity in Saudi universities.

According to Costa and Meadows [46], ICT is used to communicate between researchers. Using ICT for collaboration has other advantages, such as an increased number of publications, increased informal communications, improvements in the quality of work, and increased ease of finding relevant information. Lee and Bozeman [82], found that the collaboration between researchers and institutions is increasing. Collaboration between scientists in research fields is the main indicator in evaluating the academic staff level and university level. According to Gertrude [83], collaborative learning is an umbrella term used for a variety of educational approaches involving joint intellectual efforts by students or students and teachers together. This study agrees that using email, social networking, web CT, video conferencing, and smartphones can enhance the collaboration level between students and teachers. This means that using IT can improve international collaboration. Also, Lepori et al. [84], found that mobility is an important policy which can be applied for all academic institutions. Mobility between universities, by sending and receiving academic staff, will increase the scholarly communication between universities. This will enhance the research productivity.

Therefore, it is important to study the impact of international collaboration on academic staff in Saudi universities in order to enhance research productivity, considering the beliefs of academic staff regarding how international collaboration can be used to enhance research productivity. As most of above studies show the positive impact of international collaboration to improve the research performance.

Hypothesis 2C (H2C). International collaboration is believed by academic staff to be able to enhance publication productivity.

Industry-university relationships are an important factor which have to be provided by an organization $[24,60,85,86]$. This will help academic staff to undertake new research topics, develop 
new research questions, and provide equipment and a convenient workplace. Using a computer can enhance communication with industries to update their needs. An organisation should sign industry-university relation policies. According to Cloete [53], university policy should include all of the main objectives of the university. For example, $\mathrm{PhD}$ students and post-doctorates are the main elements that affect the progress of research productivity in universities. Moreover, the organisational policy is a powerful factor that can control both organisational factors and personal factors $[87,88]$. Shibayama and Baba [89] confirm that low mobility between academic staff in universities leads to low impact factors in publications in Japan universities.

Therefore, it is necessary to examine the impact of university policy on academic staff in Saudi universities in order to enhance research productivity according to the beliefs of academic staff regarding how university policy should be to enhance research productivity. Also, clear policy for publication in Saudi universities will lead to the sustainability of publication.

Hypothesis 2D (H2D). University policy is believed by academic staff to be an important factor in assisting publication productivity in Saudi universities.

Technical support is an organisational responsibility and should be provided by an organization [79, $90,91]$. For example, the university website, a system to measure worker appraisal, tools to help workers share their knowledge with others, various library databases, and tools for online feedback from academic staff should be provided. According to Chenine et al. [92], a distributed computer network is necessary to enhance performance in an organisation. Using a university portal helps academic staff to share their knowledge and find relevant information easily [90]. According to Ynalvez and Shrum [88], developing and developed countries need to use information technology to improve productivity and collaboration. Scholars using IT can improve the collaboration between them and assist in enhancing research productivity.

Thus, it is important to know whether the level of use of ICT in Saudi universities for research purpose can positively affect research productivity or not.

Hypothesis 2E (H2E). Different levels of ICT use at universities are correlated with publication productivity based on the beliefs of academic staff.

Next Figure 2 show the most important sub factors which explain the main factors (organizational factors)

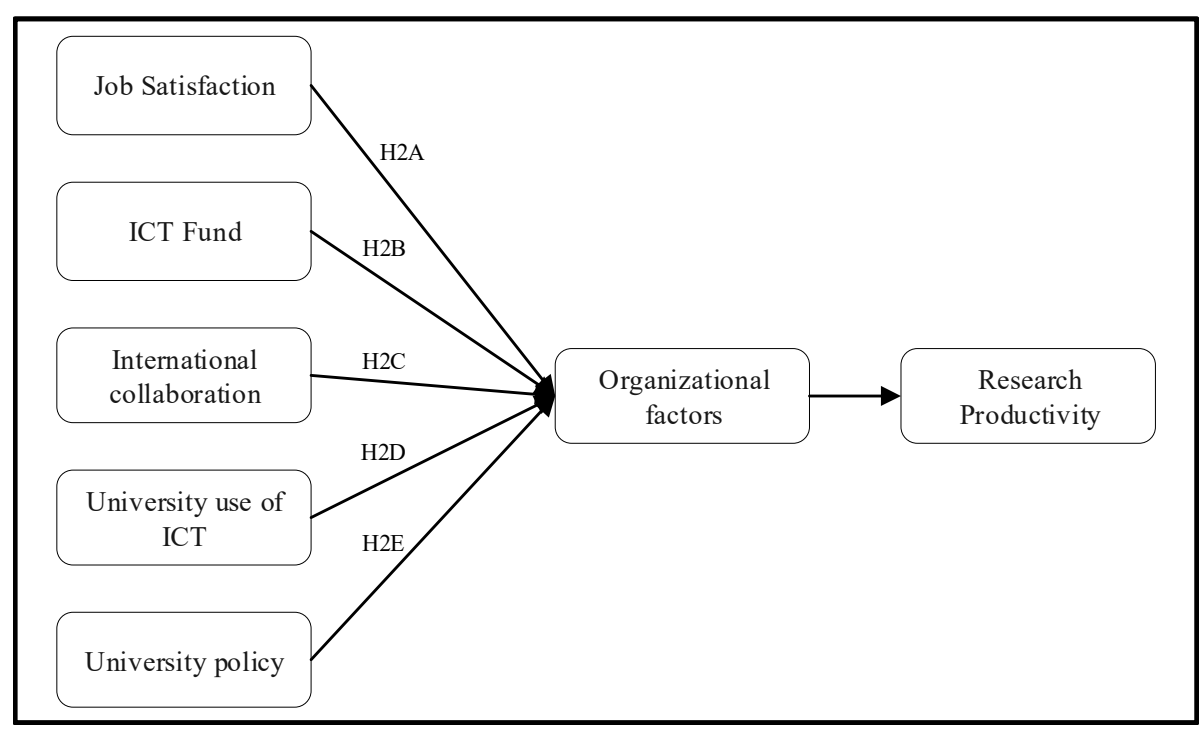

Figure 2. Organisational factors and sub-organisational factors. 


\section{Systematic Literature Review}

This paper uses an SLR as a type of data collection to find the most important factors in enhancing the sustainability of research productivity in Saudi universities. This section will include the results of the SLR. We use Microsoft Excel to collect the data and perform the analysis of the SLR results. The next section will present the framework used in this research to conduct the SLR.

Next, Figure 3 presents the frequency of use of the factors found in the SLR. The factors are the personal use of ICT, job satisfaction, international collaboration, university policy, university use of ICT and ICT funding.

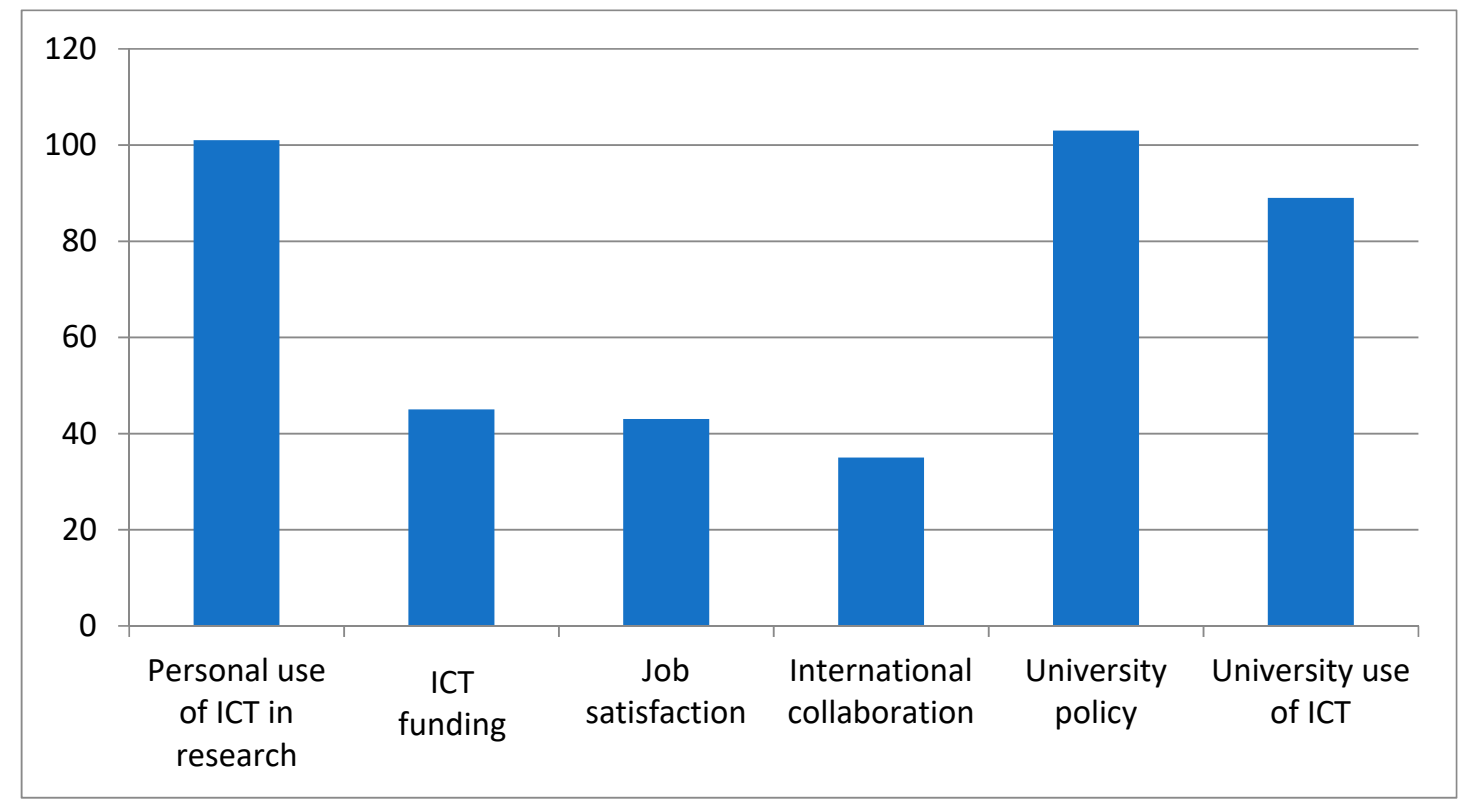

Figure 3. Frequency of use of the factors in the systematic literature review (SLR).

According to the results of the SLR, we can categorise the finding into two domains. Those domains can help an organization to assist academic staff. The first domain is personal factors, and the second is organizational factors. Figure 4 shows the frequency of use for each domain.

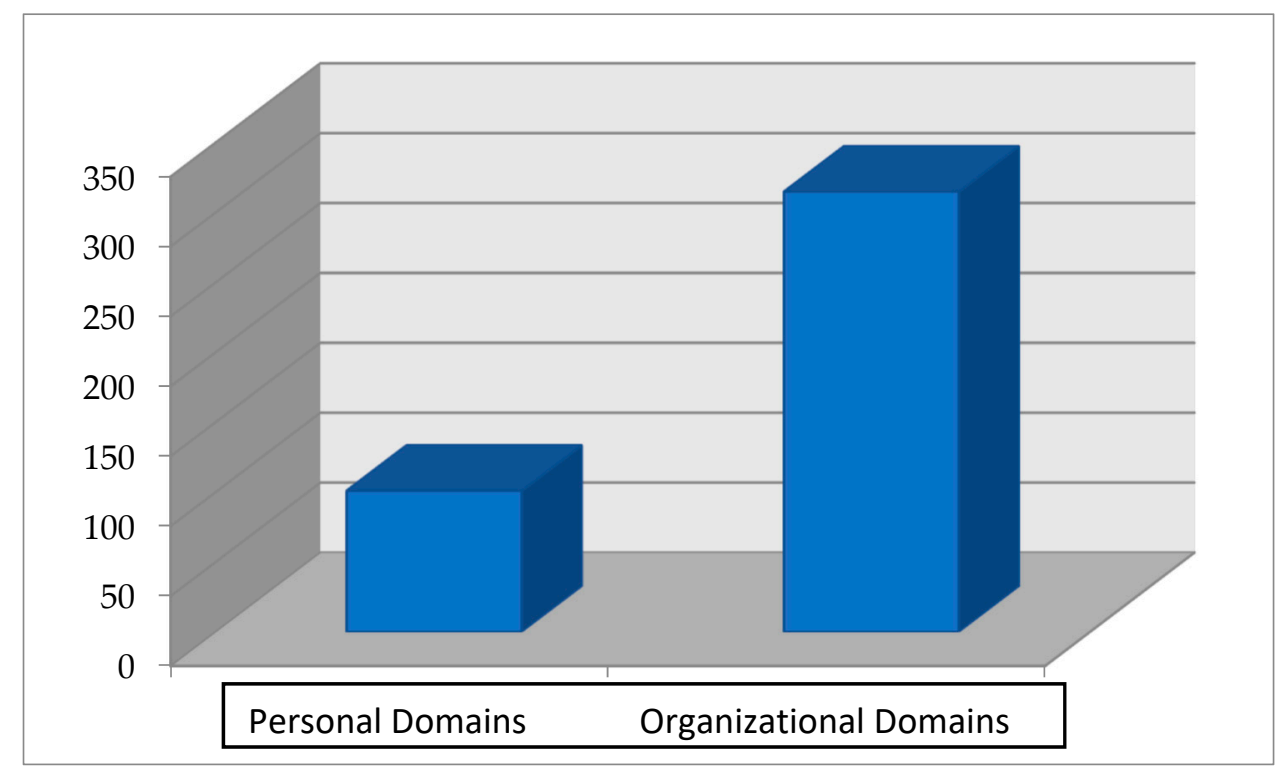

Figure 4. Frequency of use of the domains in the SLR. 
From the results of the SLR, the authors built the survey and collected data from four Saudi universities to find the relationship between the factors. In the results section, this study presents the results of testing the hypotheses.

\section{Materials and Methods}

This paper uses two methods to achieve the final results. We use an SLR, then build a questionnaire to evaluate the impact of each factor on Saudi publications. First, the authors use various databases such as Science Direct, Scopus, and IEEE to investigate the important factors affecting academic staff in order to enhance scholarly publication or increase their academic performance. The authors downloaded papers from 1993 to 2017 related to using ICT to improve scholarly publication.

After that, the authors used Microsoft Excel as a tool to finalise the outcomes of the 200 papers. The authors used more than six Excel sheets to determine the final results. Each Excel sheet included the factor's name, the paper's name, and the frequency of factor use. First, the researchers found 156 factors and sub-factors in relation to scholarly publication. All of those factors are listed in one Excel sheet called "performance factors". Second, the authors created one more sheet called "identified by domain" and used colours to define the factors. For example, if a factor referred to the personal domain, the authors used a red colour. Thirdly, the authors created two Excel sheets called "environmental" and "personal". After that, the authors copied all factors related to personal perspectives to the personal file and did the same for organisational factors. The personal domain has 50 factors and sub-factors. The organisational domain contains 105 factors and sub-factors. Then, the authors used colours to categorise the factors and sub-factors in each Excel sheet (organisational and personal). For the personal Excel sheet, the authors excluded variables that were not related to using IT. Another Excel sheet was created, called "personal factors", and included one factor and items that measure that factor. A sheet called "organisational factors" was also created and included five factors and the items to measure those factors. The next framework (Figure 5) shows the four stages the authors followed to determine the most important factors. These affect the performance of research productivity in universities.

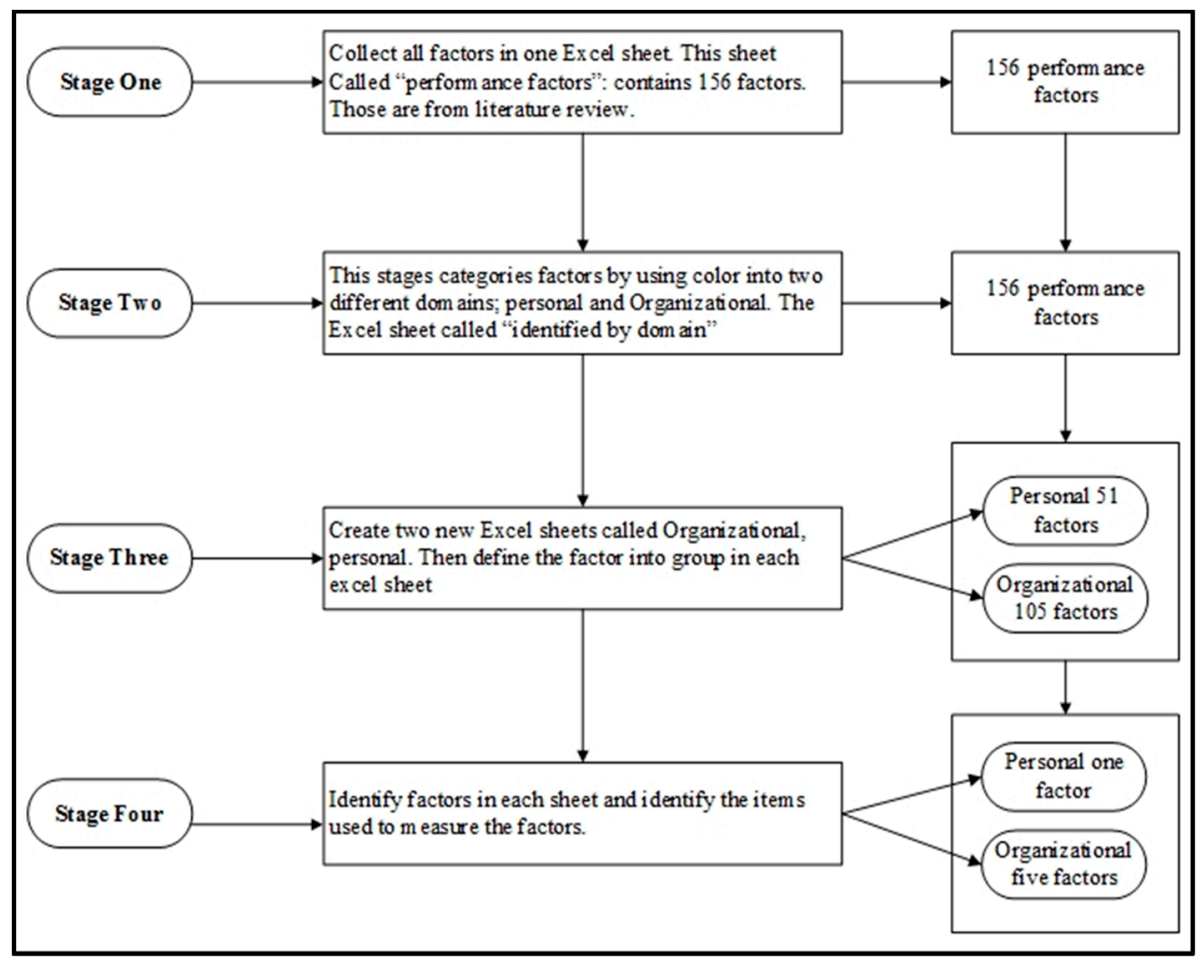

Figure 5. Model framework used in this research. 
Using systematic methods to find factors that affect academic staff helps researchers to cover the most important aspects related to scholarly publication. The researchers spent around five months to include, exclude, and identify factors. This is still a short time compared to other methods. This method is a new systematic method created by the authors to find factors. This study used SmartPLS3 to analyse data and examine the validity of the results found in the systematic review, as well as to test the relationship between factors and identify the level of significance for each of the factors to create the Importance Performance Map Analysis (IPMA).

This research sampled academic staff in developing universities in Saudi Arabia. This paper will include the three ranks of academic staff in Saudi universities according to Saudi university policy (full professor, associate professor and assistant professor). It includes Saudi and non-Saudi academic staff, both male and female. Saudi Arabia has three generations of established universities, and all of them established since 2005 are considered as under-developed universities. Saudi Arabia has 18 under-developed universities. Those universities still receive extra funding from government to build infrastructure such as IT infrastructure. All of those universities are controlled and sponsored by the Saudi government, and all of them follow the same rules for publication and promotion $[7,93]$. All previous studies conducted in Saudi Arabia selected one to four Saudi universities to collect their data [62,63]. Most of the previous studies that investigated the factors used surveys to collect data such $[7,41]$.

We selected four out of 18 universities. These four universities are from different states, and all of them have branches. Those universities are Taibah University, Jeddah University, Hail University and Taif University. The total participation in the previous studies is 374, and in this study, the number of participants is 374 . The questionnaire has two phases of validation. The first phase is the face and content validity, whereby we sent the questionnaire to 19 experts in Saudi universities. Then, the authors analysed the results and prepared for the second phase of validation. The second phase of validation was a pilot study using SmartPLS 3 to analyse the results. This study applied a measurement model to validate the items used in this questionnaire. After that, this study used a Google form to send the questionnaire to the participants in the four Saudi universities. The authors used a database provided by each university to send the questionnaire to academic staff in four under-developed universities. The authors started the data collection on 3 April 2017. The total number of distributed survey questionnaires was 2000; the number of returned completed questionnaires was 480 . After scanning the returned questionnaires, only 375 were found to be useful for data analysis. The author removed the questionnaires which had missing values, straight answers and inconsistent answers. The questionnaire was not anonymous, because this study used an online based survey.

\section{Results}

The current reality in academia shows that Saudi universities are at the lowest rank when compared with other international universities. Also, various studies agree with the importance of using IT in organisations to enhance the performance of workers. Many previous studies have showed the advantages of using ICT in universities. This paper shows that the use of IT in Saudi universities is unacceptably low $[34,94]$. Saudi universities do not pay sufficient attention to improving their IT infrastructure. Only four out of 26 universities in Saudi Arabia are using cloud computing.

We investigated the factors that impact academic staff in universities in terms of enhancing research productivity by using ICT based on the beliefs of academic staff. This study used new methods to investigate important factors in each domain. The final results show that six variables that enhance research productivity in universities, as shown in Table 1 . Those variables include the personal use of ICT, ICT funding, job satisfaction, international collaboration, university policy, and level of ICT use at the university level. The following table presents the frequency of use of each factor in the literature review. 
Table 1. The variables that enhance research productivity in universities.

\begin{tabular}{|c|c|c|c|}
\hline Main Factors & Sub Factors & Different Theme Uses for the Same Factor & $\begin{array}{l}\text { Number of } \\
\text { Citations (Scopus, } \\
\text { Google Scholar) }\end{array}$ \\
\hline Personal factors & $\begin{array}{l}\text { Personal use of } \\
\text { ICT in research }\end{array}$ & $\begin{array}{ll}\text { - } & \text { Different ability in using computers. } \\
\text { - } & \text { Different creative levels. } \\
\text { - } & \text { Different motivation levels. } \\
\text { - } & \text { Use of research software such as Turnitin. } \\
\text { - } & \text { Use of IT for documentation. } \\
\text { - } & \text { Use of e-communication. }\end{array}$ & 101 \\
\hline \multirow{5}{*}{$\begin{array}{l}\text { Organisational } \\
\text { factors }\end{array}$} & ICT funding & $\begin{array}{ll}- & \text { Funding-equipment. } \\
- & \text { Lack of computers. } \\
- & \text { Lack of IT infrastructure. } \\
\text { - } & \text { Research grants. } \\
\text { - } & \text { International licenses. }\end{array}$ & 45 \\
\hline & Job satisfaction & $\begin{array}{ll}- & \text { Salary. } \\
- & \text { Promotion. } \\
- & \text { University culture. } \\
- & \text { Leader support. } \\
- & \text { Share decision making } \\
- & \text { Teaching load. }\end{array}$ & 43 \\
\hline & $\begin{array}{l}\text { International } \\
\text { collaboration }\end{array}$ & $\begin{array}{l}\text { - Computer-based communication to } \\
\text { enhance collaboration. } \\
\text { - } \quad \text { PhD students from other } \\
\text { international universities. } \\
\text { - } \quad \text { Collaborative learning. } \\
\text { - } \quad \text { Mobility. }\end{array}$ & 35 \\
\hline & $\begin{array}{l}\text { University } \\
\text { policy }\end{array}$ & $\begin{array}{ll}\text { - } & \text { Industry-university relationships. } \\
\text { - } & \text { Research centre. } \\
\text { - } & \text { Motivation. } \\
\text { - } & \text { International staff. }\end{array}$ & 103 \\
\hline & $\begin{array}{l}\text { University use } \\
\text { of ICT }\end{array}$ & $\begin{array}{ll}\text { - } & \text { System to measure progress. } \\
\text { - } & \text { Computerized university library. } \\
\text { - } & \text { Distributed computer network. } \\
\text { - } & \text { Online feedback. }\end{array}$ & 89 \\
\hline
\end{tabular}

We explore the relationship between personal factors and organisational factors regarding research performance in Saudi universities and also investigate the importance-performance for each factor in order to allow Saudi universities to understand the important factors for enhancing research performance in Saudi universities. This research collected data from four Saudi universities, with a total of 375 academic staff responses. The authors used SmartPLS3 to analyse the data. The data were collected from 215 male and 160 female academic staff in Saudi universities. The data include different academic ranks: 200 assistant professors, 114 assistant professors, and 61 full professors. Also, the data were collected from different age groups. Sixty-seven academic staff were aged 30-35, 74 aged 36-40, 82 aged $41-45,70$ aged $46-50,36$ aged 51-55, 33 aged 56-60, and 13 were aged 61-70. 
Members of different faculties participated. This study has 53 staff members from computing, 82 from science faculties, 41 from engineering faculties, 73 from medicine faculties, 99 from education faculties, and 27 from business faculties. The participants also come from different regions. The nationality of the participants was as follows: 144 academic staff from Saudi Arabia, 84 from Egypt, 32 from Pakistan, five from the USA, two from Yemen, 7 from Malaysia, 32 from Jordan, two from Australia, three from Canada, three from Indonesia, 28 from Sudan, two from Algeria, 18 from Tunisia, six from India, six from the UK, and one from Syria.

Also, experience is an important aspect, as it mixes new academic staff opinions with old academic staff opinions regarding the enhancement of research performance in Saudi universities $[56,69]$. This study covers all different levels of experience in Saudi universities; this study includes 145 academic staff with 14 years' experience and above, 67 academic staff with 9-13 years' experience, 92 with 5-9 years' experience, and 71 new academic staff with only 1-5 years' experience. This paper considers the PhD's graduate country as a control variable. It includes 190 academic staff who graduated from Arab countries and 185 who graduated from non-Arab countries.

Collecting data across different academic ranks, ages, levels of experience, nationality, and faculties will contribute to producing more accurate results to assist an organization and help the organization to solve the problems. This study has seven constructs. Those constructs are scholarly publication (CP), ICT funding (F), international collaboration (IC), university policy (UP), university use of ICT (UU), personal use of ICT (PUC), and job satisfaction (JS). Each factor has several items. Scholarly publication has five items (CP1, CP2, CP3, CP4, CP5); ICT funding has seven items (F1, F2, F3, F4, F5, F6, F7); international collaboration has four items (IC1, IC2, IC3, IC4); university policy has ten items (UP1, UP2, UP3, UP4, UP5, UP6, UP7, UP8, UP9, UP10); university use of ICT has six items (UU1, UU2, UU3, UU4, UU5, UU6); personal use of ICT has five items (PUC1, PUC2, PUC3, PUC4, PUC5); and job satisfaction has five items (JS1, JS2, JS3, JS4, JS5). The sample of questionnaires is included in the Appendix A. The next Table 2 shows the measurement model including all constructs and items. The measurement model assessment is used to determine how the constructs are evaluated and measured [95]. Formative measurement and reflective measurement are the two types of the measurement model. In this study, all the constructs are reflective. To measure the reflective measurement model, there are a set of tests used to evaluate the internal consistency, evaluate the convergent validity and evaluate the discriminant validity. Also, we should observe the results of the extracted average variance (AVE). All of the results of the measurement meet the standard criteria list by [95]. All Cronbach's Alpha values are more than 0.6 . All of the composite reliability values are more than 0.6 . The factor loading is more than or equal to 0.7 , and the AVE is more than or equal to 0.5 .

In addition to examining the hypotheses suggested in this study, the authors used a measurement model and a structural model. According to Hair Jr et al. [96], a measurement model should test the internal consistency, convergent validity, and discriminate validity. For internal consistency, validity should be tested with the Cronbach's Alpha and Composite Reliability. The Cronbach's Alpha value should be more than 0.6 , and Composite Reliability should be more than 0.7 . The results for Cronbach's Alpha show that scholarly publication is at 0.855 , university use of ICT is at 0.842 , job satisfaction is at 0.866 , university policy is at 0.919 , personal use of ICT is at 0.864 , international collaboration is at 0.866 , and ICT funding is at 0.928 . This means that all results are higher than the standards. The results for Composite Reliability show that CP is at $0.895, \mathrm{~F}$ is at 0.942 , IC is at 0.909 , UP is at 0.932 , $\mathrm{UU}$ is at 0.884 , PUC is at 0.902 , and JS is at 0.903 . These results indicate that the internal consistency is valid for this study and that all results are higher than the standard shown by Hair Jr et al. [96]. The next test is Convergent Validity. According to Hair Jr et al. [96], the results of AVE should be 0.05 or equal, and outer loading should be 0.6 or equal. The next table presents the results of this test. For AVE, results show funding at $0.7,0.714$ for international collaboration, 0.647 for the personal use of ICT, 0.6 for university policy, 0.631 for scholarly publication, 0.6 for university use of ICT, and job satisfaction at 0.7 . These results indicate that all constructs are valid. 
Table 2. The measurement model. AVE: average variance extracted.

\begin{tabular}{|c|c|c|c|c|}
\hline Construct Name & Construct Code & AVE & \multicolumn{2}{|c|}{ Outer Loading } \\
\hline \multirow{5}{*}{ Scholarly Publication } & \multirow{5}{*}{$\mathrm{CP}$} & \multirow{5}{*}{0.631} & $\mathrm{CP} 1$ & 0.761 \\
\hline & & & $\mathrm{CP} 2$ & 0.762 \\
\hline & & & $\mathrm{CP} 3$ & 0.855 \\
\hline & & & $\mathrm{CP} 4$ & 0.816 \\
\hline & & & CP5 & 0.774 \\
\hline \multirow{7}{*}{ ICT funding } & \multirow{7}{*}{$\mathrm{F}$} & \multirow{7}{*}{0.7} & $\mathrm{~F} 1$ & 0.815 \\
\hline & & & F2 & 0.882 \\
\hline & & & F3 & 0.871 \\
\hline & & & F4 & 0.744 \\
\hline & & & F5 & 0.814 \\
\hline & & & F6 & 0.868 \\
\hline & & & F7 & 0.852 \\
\hline \multirow{4}{*}{ International Collaboration } & \multirow{4}{*}{ IC } & \multirow{4}{*}{0.714} & IC1 & 0.862 \\
\hline & & & IC2 & 0.883 \\
\hline & & & IC3 & 0.783 \\
\hline & & & IC4 & 0.85 \\
\hline \multirow{5}{*}{ Job Satisfaction } & \multirow{5}{*}{ JS } & \multirow{5}{*}{0.651} & JS1 & 0.77 \\
\hline & & & JS2 & 0.829 \\
\hline & & & JS3 & 0.857 \\
\hline & & & JS4 & 0.759 \\
\hline & & & JS5 & 0.813 \\
\hline \multirow{5}{*}{ Personal use of ICT } & \multirow{5}{*}{ PUC } & \multirow{5}{*}{0.647} & PUC1 & 0.809 \\
\hline & & & PUC2 & 0.818 \\
\hline & & & PUC3 & 0.838 \\
\hline & & & PUC4 & 0.757 \\
\hline & & & PUC5 & 0.8 \\
\hline \multirow{10}{*}{ University Policy } & \multirow{10}{*}{ UP } & \multirow{10}{*}{0.578} & UP1 & 0.741 \\
\hline & & & UP2 & 0.762 \\
\hline & & & UP3 & 0.69 \\
\hline & & & UP4 & 0.757 \\
\hline & & & UP5 & 0.759 \\
\hline & & & UP6 & 0.772 \\
\hline & & & UP7 & 0.771 \\
\hline & & & UP8 & 0.742 \\
\hline & & & UP9 & 0.789 \\
\hline & & & UP10 & 0.812 \\
\hline \multirow{6}{*}{ University use of ICT } & \multirow{6}{*}{ UU } & \multirow{6}{*}{0.56} & UU1 & 0.647 \\
\hline & & & UU2 & 0.688 \\
\hline & & & UU3 & 0.794 \\
\hline & & & UU4 & 0.793 \\
\hline & & & UU5 & 0.762 \\
\hline & & & UU6 & 0.794 \\
\hline
\end{tabular}


The next stage examines the hypotheses of this study using a structural model. This study uses path assessment to explore the relationship between constructs. Path assessment examines $\mathrm{T}$ values and $p$ values. T values should be more than 1.28 for significance. If a value is less than 1.28 , it means the value is non-significant. $p$ values show the level of significance between constructs. The next Table 3 presents the path coefficient between the factors.

Table 3. Path coefficient between the factors (Path assessment).

\begin{tabular}{cccc}
\hline Path Assessment & T Values & $p$ Values & Significant Level \\
\hline ICT Funding to scholarly publication & 1.697 & 0.045 & $* *$ \\
Policy to scholarly publication & 6.526 & 0 & $* *$ \\
\hline Personal use of ICT to scholarly publication & 2.071 & 0.019 & $*$ \\
\hline International collaboration to scholarly publication & 1.735 & 0.041 & $*$ \\
\hline University use of ICT to scholarly publication & 1.387 & 0.083 & $* * *$ \\
\hline Job satisfaction to scholarly publication & 2.666 & 0.004 & $*$
\end{tabular}

Structure Model- Path assessment

According to Hair [96], if the $p$ value is less than 0.10 , it should take $\left({ }^{*}\right)$ as the significance level, meaning a low significance level. If it is less than 0.05 , it should take $\left(^{* *}\right)$, which is a medium significance level. If the $p$ value less than 0.01 , it should take $\left.{ }^{* * *}\right)$, which indicates a strong significance level. Moreover, if the $\mathrm{T}$ value is more than 1.28 , its significance level is $10 \%$. If $\mathrm{T}$ is more than 1.96 , it is significant at $5 \%$. If it is more than 2.33 , it is significant at $1 \%$.

\section{Discussion}

This study has identified six hypotheses. The first hypothesis is that the personal use of ICT is believed by academic staff to be associated positively with publication productivity. The $\mathrm{T}$ value for this relationship is 2.071 , and the $p$ value is 0.019 , with a significance level of $\left({ }^{*}\right)$. This means that personal use of ICT in Saudi universities has a positive impact on scholarly publication according to academic staff's beliefs on using information technology for research purpose. These results are consistent with prior studies $[41-43,45,49]$. All of the previous studies indicate the positive impact of using ICT in research activities. The second hypothesis is that job satisfaction is believed by academic staff to be positively associated with publication productivity. The T value for this relation is 2.666 , and the $p$ value is 0.004 , with a significance level of $\left(^{* * *}\right)$, which is a strong level of significance. These results lead to a positive relationship between the job satisfaction of academic staff in Saudi universities and an increase of scholarly publication according to academic staff's beliefs on job satisfaction for research purposes. This result is consistent with previous studies. According to De Lourdes Machado et al. [97], academic staff are a key factor in higher education institutions. Higher education is dependent on academic staff to achieve high education objectives such as scholarly publications. The satisfaction of academic staff and their motivation is crucial for the quality of higher education. Masum et al. [56], found that all universities should investigate those factors which influence academic job satisfaction. The satisfaction of academic staff leads to better performance in teaching and research. The third hypothesis is that the availability of ICT funds is believed by academic staff to enhance research productivity in Saudi universities. The T value is 1.694 , and the $p$ value is 0.045 , with a significance level of $\left(^{* *}\right)$, the medium significance level. This shows the importance of ICT funding in Saudi universities in assisting research in order to increase scholarly publication, based on academic staff's beliefs regarding how ICT funding can enhance research productivity. The results are consistent with previous studies. According to Cloete et al. [53], funding is an essential factor to assist a universities' day-to-day activities. Universities need to find greater investment to enhance university income, which will lead to the enhancement of research productivity. According to Khademi et al. [50], funding is an important factor in improving research outcomes. International universities look to improve the relationships 
between university and industry in order to enhance research productivity. According to Wood [66], Sangowusi [49], Kärnä [75], the availability of funding to assist IT infrastructure is a powerful factor to improve scholarly publication in universities. For example, the availability of international databases has a strong impact on the enhancement of the performance of research productivity in universities.

The fourth hypothesis is that international collaboration is believed by academic staff to be able to enhance publication productivity. The T value is 1.735 , the $p$ value is 0.041 , and the significance level is at the medium level $(* *)$. These results show that international collaboration is important factors in enhancing research productivity in Saudi universities based on academic staff's beliefs. Also, previous studies have shown the positive relationship between international collaboration and scholarly publication. Kafouros et al. [98], concluded that the international collaboration of academic staff has a positive impact on enhancing research productivity in the university. International collaboration can help to develop innovative capabilities. According to Zainab [99], universities can reap many advantages from the adoption of international collaboration. International collaboration can support the funding of universities, improve the library system, share electronic tools and provide new research topics upon which to collaborate.

The next hypothesis is that university policy is believed by academic staff to be an important factor in assisting publication productivity in Saudi universities. The T value is 6.526 , the $p$ value is 0 , and the significance level is $\left({ }^{* * *}\right)$, which is the high significance level. This result indicates the positive effects of Saudi university policy on increasing scholarly publication, based on academic staff's beliefs regarding how university policy can affect the research productivity. This positive relationship is confirmed by previous studies. According to Shahbazi-Moghadam et al. [24], university policy is an important factor in achieving the objectives of any organisation. Without a policy, an organisation cannot reach the level of success which it aims to achieve. Publication and citation are objectives for any academic institution. University policies include having $\mathrm{PhD}$ and post-doctorate students, lecturer exchanges, industry-university relationships, international collaborations, knowledge sharing, publication grants, international journals, international databases and university rankings. University policy has a positive relationship with the enhancement of research productivity performance.

The final hypothesis is that different levels of use of ICT at university have a correlated relationship with publication productivity based on the beliefs of academic staff regarding how university can use IT to enhance research. The T value is 1.387 , the $p$ value is 0.083 , and the significance level is $(*)$, which is a low significance level. These results show the importance of using ICT in Saudi university management to enhance research productivity. The results of this study are supported by the results of previous studies about the level of using IT in the university and the enhancement of research productivity. According to Otaghsara et al. [90], using IT in an organisation and training staff to use ICT has a positive impact on enhancing the performance of workers in the organisation. According to AL-Sinawi et al. [91], using systems of performance appraisal for academic staff has a significant impact on the enhancement of academic staff performance. Academic staff face many obstacles to sharing their knowledge in universities. One of those obstacles is the lack of the IT infrastructure provided by universities to assist knowledge sharing [47].

Therefore, this paper agrees that personal factors have a positive impact on scholarly publication in Saudi universities and that organisational factors have a significant correlation with scholarly publication in Saudi universities. Previous results are based on the beliefs of academic staff regarding the use of information technology for research purposes and other factors such as job satisfaction, international collaboration and university policy. The next figure presents the structural model of this study. This means those factors are the main factors to improving the sustainability of publication and research in Saudi universities.

The next model (Figure 6) presents the final results from analysis of our data. This model includes two independent factors and one dependent factor. Each independent factor has sub-factors. For example, the personal factor has one sub-factor: the personal use of ICT from a research perspective. 
The second independent factor is the organisational factor. ICT funding, job satisfaction, international collaboration, and university policy are sub-factors under organisational factor (see Figure 6).

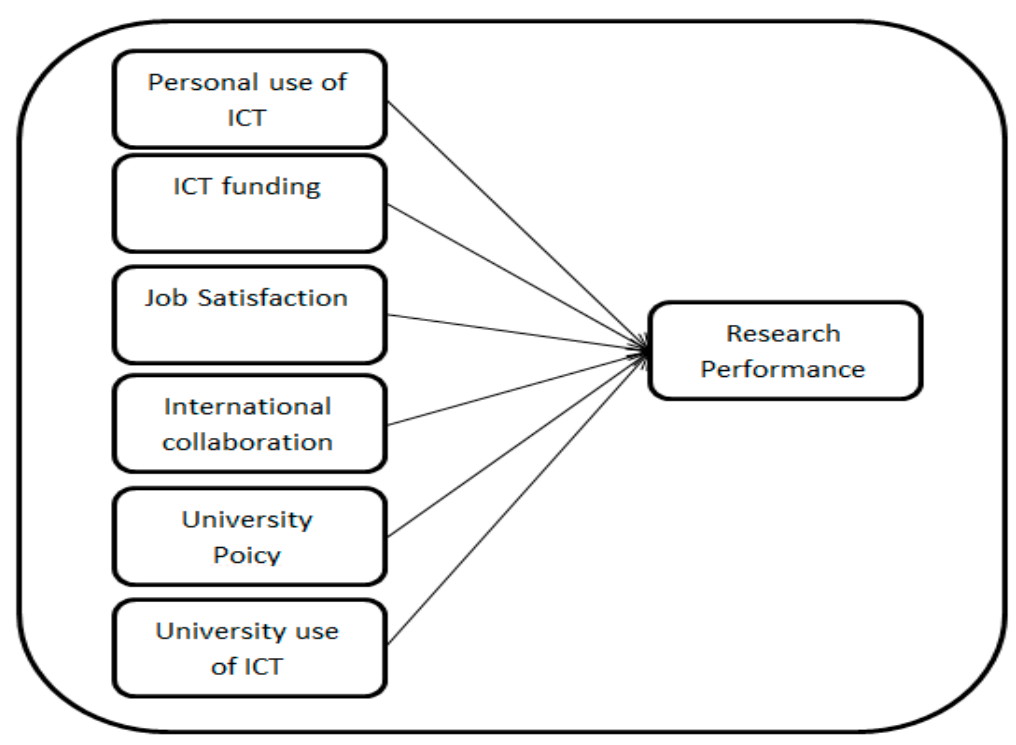

Figure 6. The final model includes all factors and sub-factors.

Finally, the last test following the structural model is the Importance-Performance Map Analysis (IPMA) as shown in Figure 7. SmartPLS3 was used to assist in finding the results of this test. This test identified the importance of the constructs in the structural model by finding the direct effect, indirect effect, and total relationship between factors [96]. According to Ahmad and Afthanorhan [100], PLS-SEM analysis finds the importance of the constructs by extracting the estimation of the direct effect, non-direct effect and the total number of relationships between the model constructs. For Colicev et al. [101], the IPMA is an important analysis method to develop the variables with high performance and current low performance in the model. Also, this type of analysis helps organisations to recognise the high constructs' performance to give these constructs consideration in the future and to identify the low constructs' performance to enhance future performance [102]. Three requirements need to be met before running an IPMA. The first is to change the latent variable score from 0-100 for all indicators and use a metric scale. Second, all construct indicators must have the same scale direction. Finally, the outer weight estimates for the measurement model should be positive, regardless of whether the model is formative or reflective [103].

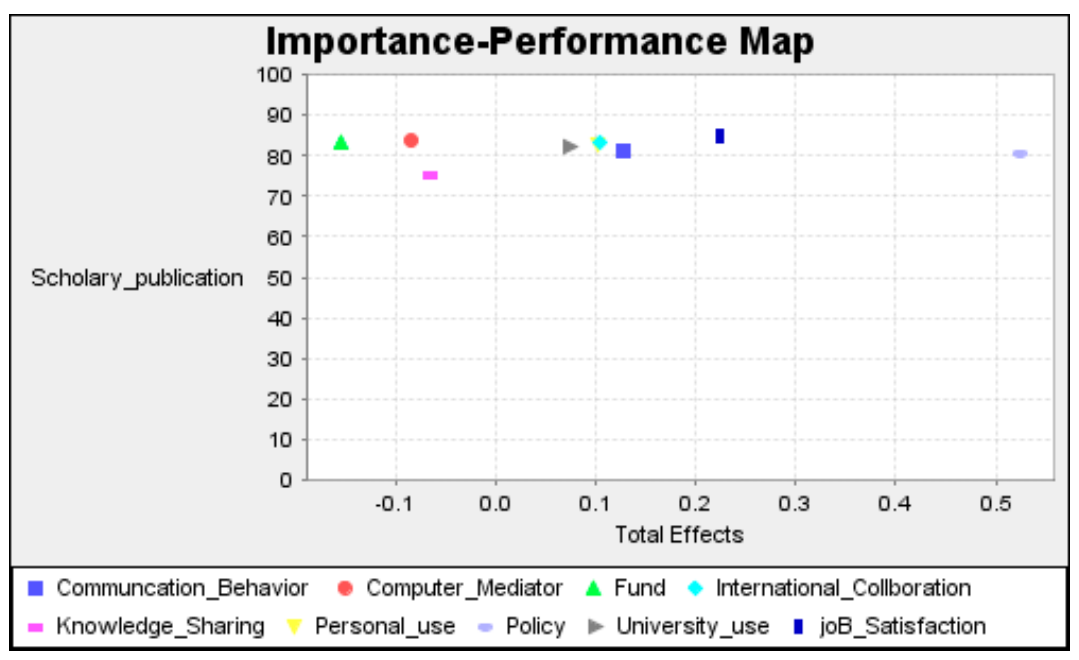

Figure 7. Importance-Performance Map Analysis. 
We used IPMA to provide guidelines for Saudi universities regarding the factors affecting academic staff in order to enhance scholarly publication. These guidelines will provide the important factors that Saudi universities have to consider to improve research productivity. Some of those factors are related to using ICT, and others are related to the satisfaction of academic staff in Saudi universities. The next Table 4 presents the importance and performance of each factor in this model for this case. According to Hair Jr et al. [96], constructs with high importance have high effects.

Table 4. Categorising the construct based on their importance.

\begin{tabular}{cccc}
\hline Independent Construct & $\begin{array}{c}\text { Importance in Enhancing } \\
\text { Scholarly Publication }\end{array}$ & Performance & $\begin{array}{c}\text { Path Coefficient } \\
\text { (Significance Level) }\end{array}$ \\
\hline Personal Factors & & \\
\hline Personal use of ICT & 0.102 & 82.708 & Significant \\
\hline ICT funding & Organisation Factors & & \\
\hline Job satisfaction & -0.156 & 83.497 & Significant \\
\hline International collaboration & 0.224 & 85.074 & Significant \\
\hline University policy & 0.103 & 88.32 & Significant \\
\hline University use of ICT & 0.523 & 80.503 & Significant \\
\hline
\end{tabular}

According to Table 4, university policy is the most important factor that influences academic staff to increase scholarly publication in Saudi universities, with an importance level of 0.523 , followed by job satisfaction at 0.224 , and international collaboration at 0.103 . Next is the personal use of ICT at an importance level of 0.102 and ICT use in Saudi universities at 0.074 . Finally, ICT funding is at an importance level of -0.156 for enhancing research productivity in Saudi universities.

This means that Saudi universities must focus more on university policies related to publication, such as using ICT to improve research activities; Postdoctoral, $\mathrm{PhD}$ and Masters programmes; using publications as indicators to measure the progress of academic staff; international collaboration; and increasing research centres. After that, Saudi universities should look into job satisfaction for their academic staff such as job security, providing training hours for using software in research, increasing salaries, and leader support. International collaboration is the third most important factor. Saudi universities should encourage academic staff to use new technology to enhance collaboration, increase international supervision, and increase mobility. Personal use of information technology is the fourth most important factor. This means that academic staff in Saudi universities should use information technologies from a research perspective, such as using research software (Mendeley, SPSS, and SmartPLS), using institutional repositories, using computer-based communication, attending e-conferences, and using library systems. The level of ICT use in universities is ranked number five among important factors. Saudi universities should provide an online discussion platform to enhance communication between academic staff, use a system to measure the progress of academic staff, integrate various databases, provide training for using IT for research, and use a system to manage research grants in the university. Finally, the availability of information technology funding is ranked number six among the important factors. Saudi universities should have a specific fund for access to international databases, developing IT infrastructure, technical support, and providing software for use in research. All of the above results are according to academic staff's beliefs, which means the level of importance is based on the beliefs of academic staff regarding to these factors.

According to Omar [104], Dhillon et al. [105], Universiti Teknologi Malaysia (UTM) uses tools to measure the academic progress of academic staff. Using tools to measure progress has a positive impact on enhancing the workers' performance [106]. According to Malaysia et al. [107], the UTM dashboard provides a library system for students and researchers, as well as software used for research 
and international collaboration. This use of ICT tools enhances the research progress of academic staff in UTM compared with Saudi universities such as Taibah University.

\section{Conclusions}

Research productivity is a critical component of increasing university rankings. It is an important indicator for evaluating the progress of academic staff in universities. Based on many studies, Arab countries need to improve the quality and quantity of their research output (publications). By enhancing the quality and quality of their research, Saudi universities can obtain comparable rankings to other international universities. Also, previous studies show that there is no sustainability in publication in Saudi universities. Utilising ICT is an important factor in improving scholarly communication, enhancing the quality of work, increasing the quantity of work, sharing knowledge, reducing work duplication, and speeding up publication. This study investigates the factors behind using ICT to enhance research productivity for academic staff in Saudi universities. Personal factors and organisational factors cover the most important aspects of universities. Therefore, the results of this study show that personal factors and organisational factors can enhance the performance of research productivity in Saudi universities based on the beliefs of academic staff regarding the use of those factors to improve research productivity. Those factors have sub-factors including the personal use of ICT in a research capacity, university policy of assisting with publications, academic staff job satisfaction, international collaboration with other staff from international universities, level of ICT use from the university, and the availability of ICT funds. Those factors will create sustainability in publication for Saudi universities. This study finds that university policy is the most critical factor for encouraging academic staff in Saudi universities to obtain more publications. Also, this study indicates the importance of research productivity to improving the rank of Saudi universities among other international universities. Thus, Saudi universities can consider those factors to build their research system and research agenda because all of those factors come from the beliefs of academic staff. Also, Saudi universities and Saudi higher education institutions can use those factors to build new policies for research purposes. The limitation of this study is the focus on using ICT to improve scholarly publications, and it is limited to investigating factors that impact academic staff in order to enhance their research performance. This study is limited to developing public universities in Saudi Arabia which are considered as under-developed universities. For future work, researchers can use ICT to enhance the discussion and interaction between academic staff and university students. Researchers can investigate the factors affecting the management level in order to enhance worker performance. According to Santos and Horta [6], having a research agenda framework will help universities to achieve their goals in the research. Finally, Saudi universities need to develop new applications to facilitate high-level management controls and measure the performance of academic staff.

Author Contributions: Conceptualization, F.G. and A.S.; methodology, F.G., A.S. and R.I; validation, F.G., A.S.,R.I., P.M and O.K.; formal analysis, F.G., A.S. and R.I; investigation, F.G., A.S. and R.I., P.M., O.K., E.H-V.; resources, F.G., A.S., R.I., P.M. and O.K.; data curation, F.G., A.S. and R.I.; writing-original draft preparation, F.G. and A.S. and R.I.; writing-review and editing, F.G., A.S., R.I., P.M., E.H-V. and O.K.; visualization, F.G. and A.S.; supervision, A.S. and R.I.; project administration, F.G., A.S. and R.I; funding acquisition, F.G., A.S., R.I., P.M. and O.K.

Funding: The authors wish to thank Universiti Teknologi Malaysia (UTM) under Research University Grant Vot-20H04, Malaysia Research University Network (MRUN) Vot 4L876 and the Fundamental Research Grant Scheme (FRGS) Vot 5F073 supported under Ministry of Education Malaysia for the completion of the research. The work is partially supported by the project of the Grant Agency of Excellence, University of Hradec Kralove, FIM, Czech Republic (ID: 2206-2019) and by the SPEV project, University of Hradec Kralove, FIM, Czech Republic (ID: 2103-2019). This project is also partially supported by the grant TIN2016-75850-R from the Spanish Ministry of Economy and Competitiveness with FEDER funds.

Acknowledgments: We are also grateful for the support of student Jan Hruska in consultations regarding application aspects. Also, we are grateful for the support from Taibah university, Madinah, Saudi Arabia.

Conflicts of Interest: Authors declare no conflict of interest. 


\section{Appendix A}

Sample of Questionnaire

Scholarly Publication (CP):

$\mathrm{CP1}$ : I believe publishing papers under ISI journals will enhance my research productivity. [78].

CP2: I believe publishing papers under Scopus journals will enhance my research productivity. [78].

CP3: I believe publishing papers with international staff from international universities will enhance my research productivity. [78].

CP4: I believe attending or presenting in scientific conference will improve my research productivity [10]. CP5: I believe publishing books or chapters will enhance my research productivity [26].

\section{ICT Fund (F)}

F1: If my university has budget to have access to international databases, it will help researchers find relevant information [53].

F2: If my university has budget to develop its IT infrastructure, it will enhance my computer use in research [50].

F3: If my university has fund to have a technical support, it will help academic staff use ICT in their research. [105]

F4: If my university allow academic staff to share their research with other sectors, it will increase income of university [53].

F5: If my university has fund to have enough computers, it will encourage academic staff use computer in their research. [54].

F6: If my university has fund to provide a great workplace and software use in research to do research, it will improve research outcomes. [68].

F7: If the Saudi Government provides universities with research budget it will motivate researchers to increase their number of researches. [26]

International Collaboration (IC)

IC1: I believe using ICT (computer-based communication) will help to enhance my international linkages [49].

IC2: I believe having good international collaborations will help me to increase number of publications. [26]

IC3: I believe having PhD students from other international universities will enhance international collaboration. [26].

IC4: I believe the mobility of academic staff can enhance international collaboration. [55].

University Policy (UP)

UP1: I believe having policy to use ICT in research will encourage academic staff to be more active. [26] UP2: Postdoctoral is important policy to enhance research productivity. [68]

UP3: Have PhD and master programs can increase the number of publications. [56]

UP4: If research productivity (publication) is one of the important indicators to evaluate academic staff, it will push academic staff to publish. [62]

UP5: I believe using international collaborations as a policy of my university will lead to good research productivity. [26].

UP6: I believe having industry university relations as a policy can enhance research outcome. [26].

UP7: I believe increasing the number of research centres should be important policy. [12].

UP8: I believe having research group will help to increase research productivity in my university. [12] UP9: Preparing research guidelines to enhancing competing between researchers will encourage academic staff to increase their research outcomes. [56] 
UP10: If my university has a reward system for publication, it will encourage academic staff to have more publication. [81].

Job Satisfaction (JS)

JS1: If my university provides suitable job security, it will make me confident to work with the university. [74]

JS2: If my university provides training about using software use in research, it will improve my research skills. [74]

JS3: If my university has an effective research management department, it will help me improve my research performance. [74]

JS4: If my university provides excellent salary and relates research productivity with salary, I will work hard to achieve university goals. [74].

JS5: If my university provides great support for research, it will help improve my research productivity. [103].

\section{Personal Use of ICT (PUC)}

PUC1: I believe using software's use in research will improve the quality of my research. [43]

PUC2: I believe using Institutional Repository and online information retrieval systems is very important for my research. [43]

PUC3: I believe using a computer based communication will enhance my communication. [47].

PUC4: I believe attending e-conferences will improve my academic skills. [70].

PUC5: I believe using our library system to access international databases will develop my research performance. [71].

\section{University Use of ICT (UU)}

UU1: I believe using online discussion can improve academic staff communication. [48]

UU2: I believe using systems to measure the academic progress can encourage academic staff to improve their academic performance. [26].

UU3: I believe using system to integrate various database will help academic staffs to find relevant information. [105]

UU4: I believe providing training on software use in research to assist publication will help to improve the research. [12].

UU5: I believe listing good journals in university website will help me to find suitable journal for my topic. [105].

UU6: I believe having system to manage research grant will enhance research productivity [105].

\section{References}

1. Ab Aziz, K.; Harris, H.; Richardson, S.; Ab Aziz, N.A. Drivers for university research performance: Investigating the researchers' dynamics. IBIMA Bus. Rev. 2012, 2012. [CrossRef]

2. Hladchenko, M.; Pinheiro, R. Implementing the Triple Helix Model: Means-Ends Decoupling at the State Level? Minerva 2019, 57, 1-22. [CrossRef]

3. Ujang, Z. Revitalizing the Soul of Higher Learning, 1st ed.; Penerbit Utm Press: Johour Bahuru, Malaysia, 2013.

4. Barnett, R. Thinking and Rethinking the University: The Selected Works of Ronald Barnett, Word of Library, London; Routledge: London, UK, 2014.

5. Damon, W.W. The Research University: Allocating Resources within Schools and among Schools. In Proceedings of the American Institute of Higher Education 6th International Conference Proceedings Volume 4-Number 1, Charleston, SC, USA, 6-8 April 2011; p. 395.

6. Santos, J.M.; Horta, H. The research agenda setting of higher education researchers. High. Educ. 2018, 76, 649-668. [CrossRef] 
7. Alzuman, A. Faculty Research Productivity in Saudi Arabian Public Universities: A Human Capital Investment Perspective. Ph.D. Thesis, Virginia Commonwealth University, Richmond, VA, USA, 2015.

8. Higher Education, S. Ministry of Education. 2018. Available online: https://www.moe.gov.sa/en/Pages/ default.aspx (accessed on 7 January 2018).

9. Al-Khalifa, H.S. Scientometric assessment of Saudi publication productivity in computer science in the period of 1978-2012. Int. J. Web Inf. Syst. 2014, 10, 194-208. [CrossRef]

10. Alhaider, S.A.; Alshehri, H.A.; Almedhesh, S.A. Research training, productivity and challenges among trainees of paediatric residency programs across Saudi Arabia. Int. J. Pediatr. Adolesc. Med. 2015, 2, 70-74. [CrossRef]

11. Wilkinson, B.R.; Durden, C.H. Inducing structural change in academic accounting research. Crit. Perspect. Account. 2014, 26, 23-36. [CrossRef]

12. Noruzi, A.; Abdekhoda, M. Scientometric analysis of Iraqi-Kurdistan universities' scientific productivity. Electron. Libr. 2014, 32, 770-785. [CrossRef]

13. Hanafi, S. University systems in the Arab East: Publish globally and perish locally vs publish locally and perish globally. Curr. Sociol. 2011, 59, 291-309. [CrossRef]

14. Ghabban, F.M.; Selamat, A.; Ibrahim, R. A Performance Measurement of Research Productivity in Saudi Universities. J. Eng. Appl. Sci. 2016, 100, 537-544.

15. Economic, S. Environmental Performance of OIC Member Countries; Social Research and Training Center for Islamic Countries: Ankara, Turkey, 2007.

16. Sidorenko, T.; Gorbatova, T. Efficiency of Russian Education Through the Scale of World University Rankings. Procedia Soc. Behav. Sci. 2015, 166, 464-467. [CrossRef]

17. Alali, A.L.I.S.; Nikolaidis, P.; Nikolaidia, P. Preliminary study of intellectual productivity in Public Universities of Saudi Arabia. Recent Adv. Comput. Sci. 2015, 269-276.

18. Staniškienè, E.; Stankevičiūtè, Ž. Social sustainability measurement framework: The case of employee perspective in a CSR-committed organisation. J. Clean. Prod. 2018, 188, 708-719. [CrossRef]

19. Brusca, I.; Labrador, M.; Larrán, M. The challenge of sustainability and integrated reporting at universities: A case study. J. Clean. Prod. 2018, 188, 347-354. [CrossRef]

20. Haliso, Y. Factors affecting information and communication technologies (ICTs) use by academic librarians in Southwestern Nigeria. Libr. Philos. Pract. 2011, 10, 571.

21. Alturise, F.; Alojaiman, B. Benefits and challenges of using ICT in Saudi Arabia universities: A literature review. In Proceedings of the International Conference on Advanced in Computing, Engineering and Learning Technologies, Abu Dhabi, United Arab Emirates, 15-16 September 2013; pp. 2-46.

22. Verbree, M.; Horlings, E.; Groenewegen, P.; van der Weijden, I.; Van den Besselaar, P. Organizational factors influencing scholarly performance: a multivariate study of biomedical research groups. Scientometrics 2015, 102, 25-49. [CrossRef]

23. Bentley, P. Cross-country differences in publishing productivity of academics in research universities. Scientometrics 2015, 102, 865-883. [CrossRef]

24. Shahbazi-Moghadam, M.; Salehi, H.; Ebrahim, N.A.; Mohammadjafari, M.; Gholizadeh, H. Effective Factors for Increasing University Publication and Citation Rate. Asian Soc. Sci. 2015, 11, 338-348. [CrossRef]

25. KACT. The Kingdom Moves Up the World List of the Annual Growth of Scientific Publication for the Last Two Years. 2013. Available online: http://www.kacst.edu.sa/en/about/media/news/Pages/news4310309-5972.aspx (accessed on 4 November 2015).

26. Ababteen, A. The Reality of Scientific Publishing in Saudi Universities; Aljazerah: Riyadh, Saudi Arabia, 4 March 2012.

27. Van der Heijden, H.; Verhagen, T.; Creemers, M. Understanding online purchase intentions: Contributions from technology and trust perspectives. Eur. J. Inf. Syst. 2003, 12, 41-48. [CrossRef]

28. Vasileiadou, E.; Vliegenthart, R. Research productivity in the era of the internet revisited. Res. Policy 2009, 38, 1260-1268. [CrossRef]

29. Michinov, N.; Primois, C. Improving productivity and creativity in online groups through social comparison process: New evidence for asynchronous electronic brainstorming. Comput. Hum. Behav. 2005, 21, 11-12. [CrossRef]

30. Steinmueller, W.E. Will new information and communication technologies improve the 'codification' of knowledge? Ind. Corp. Chang. 2000, 9, 361-376. [CrossRef] 
31. Eid, M.; Nuhu, N.A. Impact of learning culture and information technology use on knowledge sharing of Saudi students. Knowl. Manag. Res. Pract. 2011, 9, 48-57. [CrossRef]

32. Harpaz, I. Advantages and disadvantages of telecommuting for the individual, organization and society. Work. Study 2002, 51, 74-80. [CrossRef]

33. Wright, K.B. Researching Internet-based populations: Advantages and disadvantages of online survey research, online questionnaire authoring software packages, and web survey services. J. Comput. Mediat. Commun. 2005, 10, 1034. [CrossRef]

34. Alharthi, A.; Alassafi, M.O.; Walters, R.J.; Wills, G.B. An exploratory study for investigating the critical success factors for cloud migration in the Saudi Arabian higher education context. Telemat. Inform. 2017, 34, 664-678. [CrossRef]

35. Alsuraihi, M.D.; Bashraheel, H.O. Information and Communication Technologies' ICTs' in the Saudi Household. J. Asian Sci. Res. 2013, 3, 286.

36. Al-Kahtani, N.K.M.; Ryan, J.J.C.H.; Jefferson, T.I. How Saudi female faculty perceive internet technology usage and potential. Inf. Knowl. Syst. Manag. 2005, 5, 227-243.

37. Cobo, M.J.; López-Herrera, A.G.; Herrera-Viedma, E.; Herrera, F. Science mapping software tools: Review, analysis, and cooperative study among tools. J. Am. Soc. Inf. Sci. Technol. 2011, 62, 1382-1402. [CrossRef]

38. Al-Ghamdi, S.; Tight, M. Selecting and developing high-quality academic staff. In Higher Education in Saudi Arabia; Springer: Berlin/Heidelberg, Germany, 2013; pp. 83-93.

39. Yassin, F.; Salim, J.; Ashaari, N.S. The Influence of Organizational Factors on Knowledge Sharing Using ICT among Teachers. Procedia Technol. 2013, 11, 272-280. [CrossRef]

40. Fabregat-Aibar, L.; Barberà-Mariné, M.G.; Terceño, A.; Pié, L. A Bibliometric and Visualization Analysis of Socially Responsible Funds. Sustainability 2019, 11, 2526. [CrossRef]

41. Basak, S.K. A Model Using ICT Adoption and Training to Improve the Research Productivity of Academics. Ph.D. Thesis, Durban University of Technology, Durban, Africa, 2015.

42. Abrizah, A. The cautious faculty: Their awareness and attitudes towards institutional repositories. Malays. J. Libr. Inf. Sci. 2009, 14, 17-37.

43. A Balubaid, M. Using Web 2.0 Technology to Enhance Knowledge Sharing in an Academic Department. Procedia Soc. Behav. Sci. 2013, 102, 406-420. [CrossRef]

44. Siddiqui, M.A. The use of information technology in academic. J. Librariansh. Inf. Sci. 1997, 29, $195-203$. [CrossRef]

45. Ng, K.K.; Luk, C.H.; Wang, F.L.; Luk, L. The Impact of Online Discussion Platform on Students' Academic Performance. In Hybrid Learning: Innovation in Educational Practices; Springer: Hong Kong, China, 2015; pp. 199-208.

46. Costa, S.; Meadows, J. The impact of computer usage on scholarly communication among social scientists. J. Inf. Sci. 2000, 26, 255-262. [CrossRef]

47. Sohail, M.S.; Daud, S. Knowledge sharing in higher education institutions: Perspectives from Malaysia. Vine 2009, 39, 125-142. [CrossRef]

48. Ibegbulam, I.J.; Jacintha, E.U. Factors That Contribute to Research and Publication Output among Librarians in Nigerian University Libraries. J. Acad. Libr. 2016, 42, 15-20. [CrossRef]

49. Sangowusi, F.O. Problems of accessing scholarly publications by Nigerian scientists: A study of the University of Ibadan. J. Inf. Sci. 2003, 29, 127-134. [CrossRef]

50. Khademi, T.; Ismail, K.; Lee, C.T.; Shafaghat, A. Enhancing Commercialization Level of Academic Research Outputs in Research University. J. Teknol. 2015, 74, 141-151. [CrossRef]

51. Alghanim, S.A.; Alhamali, R.M. Research productivity among faculty members at medical and health schools in Saudi Arabia. Prevalence, obstacles, and associated factors. Saudi Med. J. 2011, 32, 1297-1303.

52. Franzoni, C.; Scellato, G.; Stephan, P. The mover's advantage: The superior performance of migrant scientists. Econ. Lett. 2014, 122, 89-93. [CrossRef]

53. Cloete, N.; Maassen, P.; Bailey, T. Knowledge Production and Contradictory Functions in African Higher Education; African Mind: Cape Town, South Africa, 2015.

54. Nordin, N.; Daud, N.; Osman, W. Knowledge sharing behaviour among academic staff at a public higher education institution in Malaysia. World Acad. Sci. Eng. Technol. 2012, 6, 234-241.

55. Dhillon, S.K.; Ibrahim, R.; Selamat, A. Factors associated with scholarly publication productivity among academic staff: Case of a Malaysian public university. Technol. Soc. 2015, 42, 160-166. [CrossRef] 
56. Masum, A.K.M.; Azad, M.A.K.; Beh, L.-S. Determinants of Academics' Job Satisfaction: Empirical Evidence from Private Universities in Bangladesh. PLOS ONE 2015, 10, e0117834. [CrossRef] [PubMed]

57. Abramo, G.; D’Angelo, C.A.; Di Costa, F.; Solazzi, M. University-industry collaboration in Italy: A bibliometric examination. Technovation 2009, 29, 498-507. [CrossRef]

58. Kaplan, R.S. Strategic performance measurement and management in nonprofit organizations. Nonprofit Manag. Leadersh. 2001, 11, 353-370. [CrossRef]

59. Pausch, N.C.; Neff, A.; Subbalekha, K.; Dhanuthai, K.; Sirintawat, N.; Pitak-Arnnop, P. Factors affecting scientific productivity of German oral-maxillofacial surgery training centers: A retrospective cohort study. Oral Maxillofac. Surg. 2015, 19, 259-265. [CrossRef] [PubMed]

60. D'Este, P.; Patel, P. University-industry linkages in the UK: What are the factors underlying the variety of interactions with industry? Res. Policy 2007, 36, 1295-1313. [CrossRef]

61. Alrahlah, A.A. The impact of motivational factors on research productivity of dental faculty members: A qualitative study. J. Taibah Univ. Med. Sci. 2016, 11, 448-455. [CrossRef]

62. Bajabaa, A.S. Influential Factors and Faculty Members' Practices in Technology Integration Using Iste Standards for Teacher Preparation at Taibah University-Saudi Arabia. Ph.D. Thesis, Kansas State University, Manhattan, KS, USA, 2017.

63. Alshihri, B.A. Using Google Applications as Part of Cloud Computing to Improve Knowledge and Teaching Skills of Faculty Members at the University of Bisha, Bisha, Saudi Arabia. Ph.D. Thesis, Wayne State University, Detroit, MI, USA, 2017.

64. Musiige, G.; Maassen, P. Faculty perceptions of the factors that influence research productivity at Makerere University. In Knowledge Production and Contradictory Functions in African Higher Education; African Mind: Cape Town, South Africa, 2015.

65. Bengoa, M.; Martínez-San Román, V.; Pérez, P. Do R\&D activities matter for productivity? A regional spatial approach assessing the role of human and social capital. Econ. Model. 2017, 60, 448-461.

66. Wood, F. Factors influencing research performance of university academic staff. High. Educ. 1990, 19, 81-100. [CrossRef]

67. Raza, M.M.; Upadhyay, A.K. Usage of e-journals by researchers in Aligarh Muslim University: A study. Int. Inf. Libr. Rev. 2013, 38, 170-179. [CrossRef]

68. Al-Shanbari, H.; Meadows, A. Problems of communication and information-handling among scientists and engineers in Saudi universities. J. Inf. Sci. 1995, 21, 473-478. [CrossRef]

69. Hanssen, T.E.S.; Jørgensen, F.; Larsen, B. The relation between the quality of research, researchers' experience, and their academic environment. Scientometrics 2018, 114, 933-950. [CrossRef]

70. Lacy, F.J.; Sheehan, B.A. Job satisfaction among academic staff: An international perspective. High. Educ. 1997, 34, 305-322. [CrossRef]

71. Basak, S.K.; Govender, D.W. Theoretical Framework of the Factors Affecting University Academics' Job Satisfaction. Int. Bus. Econ. Res. J. 2015, 14, 317-326. [CrossRef]

72. Hamermesh, D.S.; Pfann, G.A. Reputation and earnings: The roles of quality and quantity in academe. Econ. Inq. 2012, 50, 1-16. [CrossRef]

73. Shin, J.C.; Jung, J. Academics job satisfaction and job stress across countries in the changing academic environments. High. Educ. 2014, 67, 603-620. [CrossRef]

74. Robinson-Garcia, N.; Torres-Salinas, D.; Herrera-Viedma, E.; Docampo, D. Mining university rankings: Publication output and citation impact as their basis. arXiv 2019, arXiv:1905.07141.

75. Kärnä, S.; Julin, P. A framework for measuring student and staff satisfaction with university campus facilities. Qual. Assur. Educ. 2015, 23, 47-66. [CrossRef]

76. Shirazi, A. Barriers affecting contribution of developing countries social scientists in ISI indexed Journals. Inf. Manag. Bus. Rev. 2011, 3, 39-47.

77. Mairesse, J.; Greenan, N.; Topiol-Bensaid, A. Information Technology and Research and Development Impacts on Productivity and Skills: Looking for Correlations on French Firm Level Data; National Bureau of Economic Research: Cambridge, MA, USA, 2001.

78. Brynjolfsson, E.; Hitt, L.M. Beyond Computation: Information Technology, Organizational Transformation and Business Performance. J. Econ. Perspect. 2000, 14, 23-48. [CrossRef] 
79. Watson-Manheim, M.B.; Belanger, F. Exploring communication-based work processes in virtual work environments. In Proceedings of the 35th Annual Hawaii International Conference on System Sciences (HICSS), Big Island, HI, USA, 10 January 2002; pp. 3604-3613.

80. Melville, N.; Kraemer, K.; Gurbaxani, V.; Ew, M. Review: Technology Information an Performance: Organizational Integrative Model of IT Business. MIS Q. 2004, 28, 283-322. [CrossRef]

81. Pavel, A.-P.; Fruth, A.; Neacsu, M.-N. ICT and E-Learning-Catalysts for Innovation and Quality in Higher Education. Procedia Econ. Financ. 2015, 23, 704-711. [CrossRef]

82. Lee, S.; Bozeman, B. The Impact of Research Collaboration on Scientific Productivity. Soc. Stud. Sci. 2005, 35, 673-702. [CrossRef]

83. Ezekoka; Gertrude, K. Maximizing the Effects of Collaborative Learning through ICT. Procedia Soc. Behav. Sci. 2015, 176, 1005-1011. [CrossRef]

84. Lepori, B.; Seeber, M.; Bonaccorsi, A. Competition for talent. Country and organizational-level effects in the internationalization of European higher education institutions. Res. Policy 2015, 44, 789-802. [CrossRef]

85. Salimi, N.; Bekkers, R.; Frenken, K. Does working with industry come at a price? A study of doctoral candidates' performance in collaborative vs. non-collaborative Ph. D. projects. Technovation 2015, 41, 51-61. [CrossRef]

86. Fontana, R.; Geuna, A.; Matt, M. Factors affecting university-industry R\&D projects: The importance of searching, screening and signalling. Res. Policy 2006, 35, 309-323.

87. Haghighatian, M.; Ezati, Y. An Investigation into Effective Factors on Human Resources Productivity (Case Study: Region 11, Islamic Azad University, Iran). Procedia Soc. Behav. Sci. 2015, 205, 601-607. [CrossRef]

88. Ynalvez, M.A.; Shrum, W.M. Professional networks, scientific collaboration, and publication productivity in resource-constrained research institutions in a developing country. Res. Policy 2011, 40, 204-216. [CrossRef]

89. Shibayama, S.; Baba, Y. Impact-oriented science policies and scientific publication practices: The case of life sciences in Japan. Res. Policy 2015, 44, 936-950. [CrossRef]

90. Otaghsara, M.K.; Mohseni, A.; Khalili, M. The Role of ICT in-Service Training of Employees of Government Organization (Case Study: Institute of Water and Power Unit, Mazandaran). Procedia Soc. Behav. Sci. 2012, 47, 1985-1990. [CrossRef]

91. Al-Sinawi, S.; Piaw, C.Y.; Idris, A.R. Factors Influencing the Employees' Service Performance in Ministry of Education in Sultanate of Oman. Procedia Soc. Behav. Sci. 2015, 197, 23-30. [CrossRef]

92. Chenine, M.; Nordstrom, L.; Johnson, P. Factors in Assessing Performance of Wide Area Communication Networks for Distributed Control of Power Systems. In Proceedings of the 2007 IEEE Lausanne Power Tech, Lausanne, Switzerland, 1-5 July 2007; pp. 1682-1687.

93. Arabia, S. Policy of Workers at Saudi Arabia; Saudi Government: Riyadh, Saudi Arabia, 2019.

94. Al-Maliki, S.Q.A.K. Information and communication technology (ICT) investment in the Kingdom of Saudi Arabia: Assessing strengths and weaknesses. J. Organ. Knowl. Manag. 2013, 2013. [CrossRef]

95. Hair, J.F., Jr.; Sarstedt, M.; Hopkins, L.; Kuppelwieser, V.C. Partial least squares structural equation modeling (PLS-SEM) An emerging tool in business research. Eur. Bus. Rev. 2014, 26, 106-121. [CrossRef]

96. Hair, J.F., Jr.; Hult, G.T.M.; Ringle, C.; Sarstedt, M. A Primer on Partial Least Squares Structural Equation Modeling (PLS-SEM); Sage Publications: Saunders Oaks, CA, USA, 2016.

97. De Lourdes Machado, M.; Soares, V.M.; Brites, R.; Ferreira, J.B.; Gouveia, O.M.R. A look to academics job satisfaction and motivation in Portuguese higher education institutions. Procedia Soc. Behav. Sci. 2011, 29, 1715-1724. [CrossRef]

98. Kafouros, M.; Wang, C.; Piperopoulos, P.; Zhang, M. Academic collaborations and firm innovation performance in China: The role of region-specific institutions. Res. Policy 2015, 44, 803-817. [CrossRef]

99. Zainab, A.N. Publication productivity, focus on institutional, collaborative and communicational correlates: A review of literature. Malays. J. Libr. Inf. Sci. 2000, 5, 53-94.

100. Ahmad, S.; Afthanorhan, W.M.A.B.W. The importance-performance matrix analysis in partial least square structural equation modeling (PLS-SEM) with smartpls 2.0 M3. Int. J. Math. Res. 2014, 3, 1.

101. Colicev, A.; De Giovanni, P.; Vinzi, V.E. An empirical investigation of the antecedents of partnering capability. Int. J. Prod. Econ. 2016, 178, 144-153. [CrossRef]

102. Höck, C.; Ringle, C.M.; Sarstedt, M. Management of multi-purpose stadiums: Importance and performance measurement of service interfaces. Int. J. Serv. Technol. Manag. 2010, 14, 188-207. [CrossRef] 
103. Ringle, C.M.; Sarstedt, M. Gain more insight from your PLS-SEM results: The importance-performance map analysis. Ind. Manag. Data Syst. 2016, 116, 1865-1886. [CrossRef]

104. Omar, W. Realising UTM Global Consensus, Hnclusiveness @ Engagement, 1st ed.; Panerbit Utm Press: Kuala, Malaysia, 2014.

105. Dhillon, S.K.; Ibrahim, R.; Selamat, A.; Sani, S.I. Diagnosis of Key Performance Indicators Delivery Process Using Viable System Model. Int. J. Digit. Content Technol. Appl. 2013, 7, 64.

106. Onashile, A. Impact of Performance Appraisal on Employees Productivity; Seinäjoki University of Applied Sciences: Seinajoki, Finland, 2017.

107. Universiti Teknology Malaysia. Utm Dashborad for Reseracher. 2018. Available online: https://my.utm.my/ iportal.php (accessed on 17 December 2018).

(C) 2019 by the authors. Licensee MDPI, Basel, Switzerland. This article is an open access article distributed under the terms and conditions of the Creative Commons Attribution (CC BY) license (http://creativecommons.org/licenses/by/4.0/). 